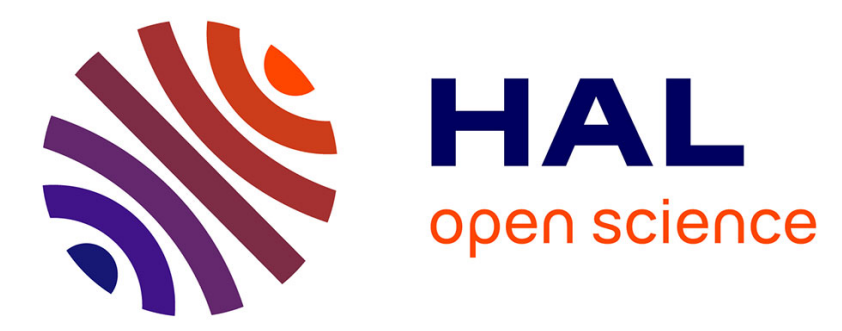

\title{
Time constraints on the closure of the Paleo-South China Ocean and the Neoproterozoic assembly of the Yangtze and Cathaysia blocks: Insight from new detrital zircon analyses
}

Chaolei Yan, Liangshu Shu, Michel Faure, Yan Chen, Renbo Huang

\section{To cite this version:}

Chaolei Yan, Liangshu Shu, Michel Faure, Yan Chen, Renbo Huang. Time constraints on the closure of the Paleo-South China Ocean and the Neoproterozoic assembly of the Yangtze and Cathaysia blocks: Insight from new detrital zircon analyses. Gondwana Research, 2019, 73, pp.175-189. 10.1016/j.gr.2019.03.018 . insu-02139064

\section{HAL Id: insu-02139064 \\ https://hal-insu.archives-ouvertes.fr/insu-02139064}

Submitted on 10 Jul 2019

HAL is a multi-disciplinary open access archive for the deposit and dissemination of scientific research documents, whether they are published or not. The documents may come from teaching and research institutions in France or abroad, or from public or private research centers.
L'archive ouverte pluridisciplinaire HAL, est destinée au dépôt et à la diffusion de documents scientifiques de niveau recherche, publiés ou non, émanant des établissements d'enseignement et de recherche français ou étrangers, des laboratoires publics ou privés. 


\section{Accepted Manuscript}

Time constraints on the closure of the Paleo-South China Ocean and the Neoproterozoic assembly of the Yangtze and Cathaysia blocks: Insight from new detrital zircon analyses

Chaolei Yan, Liangshu Shu, Michel Faure, Yan Chen, Renbo Huang

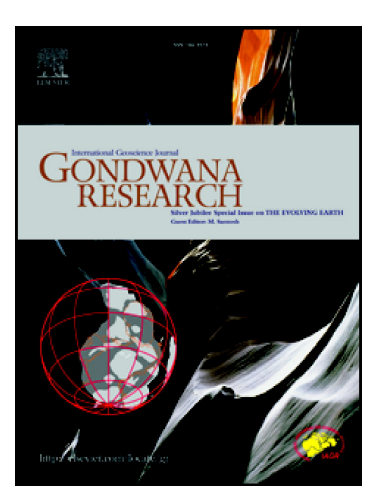

PII: S1342-937X(19)30119-4

DOI: https://doi.org/10.1016/j.gr.2019.03.018

Reference: GR 2139

To appear in:

Gondwana Research

Received date:

1 December 2018

Revised date: 26 March 2019

Accepted date:

27 March 2019

Please cite this article as: C. Yan, L. Shu, M. Faure, et al., Time constraints on the closure of the Paleo-South China Ocean and the Neoproterozoic assembly of the Yangtze and Cathaysia blocks: Insight from new detrital zircon analyses, Gondwana Research, https://doi.org/10.1016/j.gr.2019.03.018

This is a PDF file of an unedited manuscript that has been accepted for publication. As a service to our customers we are providing this early version of the manuscript. The manuscript will undergo copyediting, typesetting, and review of the resulting proof before it is published in its final form. Please note that during the production process errors may be discovered which could affect the content, and all legal disclaimers that apply to the journal pertain. 


\title{
Time constraints on the closure of the Paleo-South China Ocean and the
}

\section{Neoproterozoic assembly of the Yangtze and Cathaysia blocks: insight from new}

\section{detrital zircon analyses}

\author{
Chaolei Yan ${ }^{1,2}$, Liangshu Shu ${ }^{1, *}$, Michel Faure ${ }^{2}$, Yan Chen², Renbo Huang ${ }^{1}$ \\ ${ }^{1}$ State Key Laboratory for Mineral Deposits Research, School of Earth Sciences and \\ Engineering, Nanjing University, 210023 Nanjing, China \\ ${ }^{2}$ Univ. Orléans, CNRS, BRGM, ISTO, UMR 7327, F-45071, Orléans, France
}

\begin{abstract}
The South China Block was built up by the assembly of the Yangtze and Cathaysia blocks along the Neoproterozoic Jiangnan Orogenic Belt. The timing of the Jiangnan Orogeny remains controversial. The widespread orogeny-related Neoproterozoic angular unconformity that separates the underlying folded Sibao (ca.1000-820 Ma) and overlying Danzhou (ca.800-720 Ma) Groups was investigated. Six sedimentary samples, below and above the unconformity in three distal localities (Fanjingshan, Madiyi, and Sibao) yield detrital zircon with $\mathrm{U}-\mathrm{Pb}$ ages ranging from $779 \pm 16 \mathrm{Ma}$ to $3006 \pm 36 \mathrm{Ma}$, with a prominent peak at ca. $852 \mathrm{Ma}$. The youngest ages of $832 \pm 11 \mathrm{Ma}$ and $779 \pm 16 \mathrm{Ma}$ are revealed for the underlying Sibao and overlying Danzhou Groups, respectively. The detrital zircon $\mathrm{U}-\mathrm{Pb}$ age relative probability plot of the Jiangnan Orogen matches well with those of the Yangtze and Cathaysia blocks since ca. 865 Ma. Integrating geological, geochemical and geochronological results, we suggest that the PaleoSouth China Ocean began to subduct under the Yangtze block at ca. $1000 \mathrm{Ma}$, and was partly closed at ca. 865 Ma. Afterwards, the Yangtze and Cathaysia blocks initially collide at $865 \mathrm{Ma}$, forming the Jiangnan Orogen. This collision resulted in not only the folding of the Sibao Group, but also sediment deposition in a syn-collisional setting, which makes the upper part of the Sibao
\end{abstract}


Group. The youngest S-type granite dated at ca. 820 Ma that intruded in the Sibao Group marks the late stage of the Jiangnan Orogeny.

Key words: South China; Jiangnan Orogenic Belt; Neoproterozoic unconformity; Sibao Group; Detrital zircon geochronology

\section{Introduction}

The Jiangnan Orogen plays a key role in the tectonic framework of the South China Block, making the Neoproterozoic collision between the Cathaysia and Yangtze blocks. Over the past decades, advances in research on the Jiangnan Orogen led authors to propose several controversial tectonic models. The presence of remnants of oceanic crust and the well-defined suture zones make the eastern sector of the Jiangnan orogen commonly acknowledged as a collision belt (e.g., Li et al., 2007; Zhao and Cawood, 2012; Charvet, 2013; Shu et al., 2014; Fig. 1). However, in the western part of the Jiangnan Orogen, some issues remain to be clarified.

One of the most debated questions is the timing of the collision between the Yangtze and Cathaysia blocks. Some researchers proposed that this collision took place at $1.2-1.1 \mathrm{Ga}$ in the western part, but later in the eastern part at 1.0-0.96 Ga according to the tuff and basin study (Greentree et al., 2006). Li et al. (2007) proposed that the Jiangnan Orogen was related to the assembly of the Rodinia supercontinent during $1041-1015$ Ma by the insight of mica ${ }^{40} \mathrm{Ar} /{ }^{39} \mathrm{Ar}$ dating of the Tianli schist in the Jiangxi Province. While some authors hold the view that the collision between the two blocks should be constrained at 1.0-0.86 Ga owing to the insights of ophiolites, and arc related rocks (Shu and Charvet 1996; Ye et al., 2007; Li et al., 2008a, 2009, 2014; Zheng et al., 2008). Meanwhile, considering the peak of detrital zircon of the Sibao Group (and its equivalents) as well as the peraluminous granites distributed along the Jiangnan 
Orogenic Belt, a school of researchers suggested that the collision of the Yangtze and Cathaysia blocks took place at 850-800 Ma (Wang et al., 2007, 2008; Yao et al., 2014a, 2014b). Recently, more and more mafic rocks dated at 850-820 Ma, have been reported in the Jiangnan Orogen (Liu et al., 2015; Xia et al., 2015; Zhang et al., 2016; Sun et al., 2017). These rocks are interpreted as magmatic arc-related, consequently, the authors considered that the collision of the Yangtze and Cathaysia blocks did not started until 820 Ma. However, some authors considered that the sedimentary hiatus between the Sibao Group (and its equivalents) and Danzhou Group (and its equivalents) is the consequence of the Jiangnan Orogeny, leading the authors to propose that the collision should occur at ca. 830-800 Ma (Su et al., 2008; Zhao and Cawood, 2012; Shu et al., 2019).

In order to advance the debate on depositional time of the Sibao Group as well as the timing of the Jiangnan Orogeny, we have carried out detrital zircon dating above and below the Neoproterozoic unconformity in three distinct localities, and synthesized similar studies by integrating the new and previous data from the Jiangnan Orogen, the Yangtze and Cathaysia blocks, to improve the understanding of the Neoproterozoic tectonic evolution of the Jiangnan Orogenic Belt.

\section{Geological setting}

\subsection{The general framework of the Jiangnan Orogen}

The Jiangnan Orogenic Belt locates in the southeastern margin of the Yangtze Block, tracing the northwestward subduction of the Paleo-South China Ocean and the collision between the Yangtze and Cathaysia blocks (e.g., Guo et al., 1989; Shu et al., 1995, 2014, 2015; Li et al., 2007; Wang et al., 2007; Shu, 2012; Zhao and Cawood, 2012; Charvet, 2013; Yao et al., 2014a; 
Yan et al., 2015; Guo and Gao, 2017). The Paleo-South China Ocean subducted beneath the Yangtze Block since ca. 1000 Ma (Wang et al., 2007, 2008; Yao et al., 2014b), and the final closure of the Paleo-South China Ocean resulted in the collision between the Jiangnan magmatic arc and the Cathaysia Block (Shu, 2012; Wang et al., 2012b). Numerous ultramafic, mafic magmatic (gabbro, diorite), and volcanic rocks, interpreted as ophiolites, dated from ca. $1000 \mathrm{Ma}$ to ca. $870 \mathrm{Ma}$, distribute along the suture zone (BGMRAH, 1982; BGMRJX, 1984; BGMRZJ, 1989; Xia et al., 2018). In the Dexing-Shexian area of eastern part of the Jiangnan belt, blueschists are dated at $866 \pm 14$ Ma applying the K-Ar method on glaucophane (Shu et al, 1994; Shu and Charvet, 1996). The collision led to intensive folding and faulting, but weak metamorphism of the Sibao Group and its equivalents (see Section 2.2; BGMRGX, 1985; BGMRHN, 1988). Afterwards, the Jiangnan Orogenic Belt was intruded by peraluminous granite

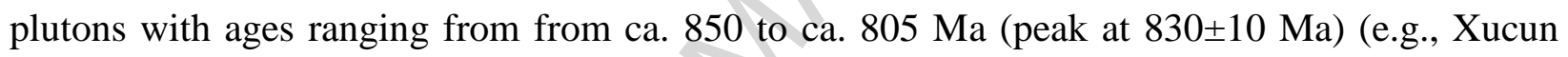
pluton, Jiuling pluton, Yuanbaoshan pluton, Sanfang pluton; Fig. 1) along the Jiangnan Orogen (Guo et al., 1989; Zhou et al., 2009; Zhang et al., 2013; Yao et al., 2014b; Xin et al., 2017). After the formation of the South China Block, this continent started to rift probably reworking the preexisting faults related to the Jiangnan Orogeny, the Piangxiang-Qidong-Quanzhou-Longsheng suture zone in the middle Neoproterozoic turned into normal fault along the northern boundary of the middle Hunan extensional basin in the Nanhua Period (Shu et al., 2019). The Nanhua rifting was coeval with the generation of ca. $800 \mathrm{Ma}-750 \mathrm{Ma}$ bimodal igneous rocks (Wang and Li, 2003; Li et al., 2018; Xia et al., 2018; Zhang et al., 2018).

Afterwards, the South China was reworked by three prominent orogenic cycles in the Phanerozoic period, including the early Paleozoic, Triassic, and Jurassic-Cretaceous tectonic events (Faure et al., 2009; Charvet, 2013; Xu et al., 2015; Li et al., 2016a). 


\subsection{Neoproterozoic stratigraphic sequences of the South China Block}

In South China, the early Neoproterozoic strata (contemporary with the Sibao Group, ca. 1000-820 Ma, (Zhou et al., 2016)) are distributed geographically in three parts. One part that crops out in the northern and western boundaries of the Yangtze Block (Fig. 1) mainly consists of sandstone and mudstone (Wang and Li, 2003). The second part, exposed within the Jiangnan Orogen, is characterized by greywacke, sandstone, mudstone enclosing mafic and ultramafic blocks. This part is generally interpreted as the consequence of the subduction of the Paleo-South China Ocean (Zhou et al., 2009; Wang et al., 2012a; Shu et al., 2014; Yao et al., 2014b). The third part is sporadically exposed in the Cathaysia Block, particularly in the northern part of the Fujian province. It is composed of terrigenous clastic rocks interlayered with volcanic rocks (BGMRFJ, 1985; Xu et al., 2010).

During the middle Neoproterozoic rifting (ca. 800-720 Ma) of the unified South China Block, more than $5 \mathrm{~km}$-thick terrigenous and volcano-clastic series were deposited. Although the formation names, such as Banxi, Danzhou and Xiajiang Groups (ca. 800-720 Ma, (Zhou et al., 2016)) vary depending on the Provinces, they are petrographically and structurally equivalent (BGMRGZ, 1984; BGMRGX, 1985; BGMRHN, 1988). According to sedimentology, at that time, a littoral-neritic depositional environment characterized the whole South China Block (Shu, 2012). However, the water depth in the Jiangnan region was deeper than that in the Yangtze and Cathaysia regions (Wang and Li, 2003; Xu et al., 2010). The middle Neoproterozoic strata (ca. 800-720 Ma) are mainly composed of fine grain conglomerate, sandstone and siltstone, and widely exposed in the Jiangnan and the Cathaysia regions but rarely revealed in the Yangtze region (Zhao and Cawood, 2012; Fig. 1). 


\subsection{Comparison of the Sibao Group (and its equivalents) and Danzhou Group (and its equivalents) in the Jiangnan Orogenic Belt}

The early Neoproterozoic and middle Neoproterozoic strata have different names in various places, e.g., the Sibao Group, Fanjingshan Group, Lengjiaxi Group, Shuangqiaoshan Group, Shangxi Group and Shuangxiwu Group of the early Neoproterozoic strata were named in the Guangxi province, Guizhou province, Hunan province, Jiangxi province, Anhui province and Zhejiang province, respectively, where the middle Neoproterozoic strata were named the Danzhou Group, Xiajiang Group, Banxi Group, Dengshan Group, Likou Group and Heshangzhen Group, correspondingly (BGMRAH, 1982; BGMRGZ, 1984; BGMRJX, 1984; BGMRGX, 1985; BGMRHN, 1988; BGMRZJ, 1989).

The deformation of the Sibao Group and its equivalents is characterised by N-S and NE-SW striking trending folds (Fig. 3). Tight folds with vertical axes are also common at the outcrop scale (Shu, 2012). The deformation is coeval with a low-grade regional metamorphism represented by low greenschist facies metamorphic rocks, such as slate, phyllite, and metavolcanic rocks. Locally, garnet-biotite micaschist and amphibole schist are observed (Charvet, 2013; Zhang et al., 2013; Yan et al., 2015; Fig. 4). These strata were unconformably overlain by the Middle Neoproterozoic Danzhou Group and its equivalents basal conglomerate (Wang and Li, 2003; Wang et al., 2007; Fig. 3). On the contrary to the Sibao Group, the Danzhou Group and its equivalents display gentle folds and a very low grade metamorphism, or even no metamorphism (Fig. 4). The Sibao Group and its equivalents contain ultramafic and mafic magmatic rocks, and siliceous sedimentary rocks interpreted as olistoliths (Yao et al., 2016). It is worthy to note that such mafic or ultramafic blocks are never observed in the Danzhou Group and its equivalents (Fig. 1). 


\subsection{Ophiolitic mélange and magmatic events in the Jiangnan Orogenic Belt}

Two ophiolitic mélanges in the eastern part of Jiangnan Orogenic Belt are generally accepted by the researchers. One is in the NE Jiangxi province, another is located near the PingxiangJiangshan-Shaoxing fault, both of them are thought to be formed in an accretionary complex defining the ophiolitic suture of the Paleo-South China Ocean. The NE Jiangxi ophiolitic rocks yielded Sm-Nd isochron ages of $1024 \pm 30 \mathrm{Ma}$ (gabbro) (Zhou et al., 1989) and $1034 \pm 24 \mathrm{Ma}$ (ophiolitic mélange) (Chen et al., 1991), SHRIMP zircon U-Pb ages of $968 \pm 23 \mathrm{Ma}$ (ophiolitic mélange) (Li et al., 1994), and 970 \pm 21 Ma (plagiogranite) (Gao et al., 2009), and SIMS zircon U-Pb age of $993 \pm 12 \mathrm{Ma}$ (gabbro) (Wang et al., 2015). They yield that a Neoproterozoic marginal sea between the Zhanggong terrane and the Huaiyu terrane (Shu et al., 1995, 2006, 2019). Recently, Yao et al. (2016) dated a gabbroic block enclosed in an ophiolitic mélange at $869 \pm 9 \mathrm{Ma}$ (zircon, LA-ICP-MS) in the Longsheng area, in the western part of the Jiangnan Orogenic Belt (Fig. 1), which represents a Neoproterozoic suture zone of the Yangtze and the Cathaysia blocks. Accordingly, it is accepted that the subduction of the Paleo-South China Ocean under the Yangtze Block already began at ca. 1000 Ma and at least lasted until to ca. 869 Ma.Previous studies indicate that the subduction related rocks are relatively well exposed in the eastern Jiangnan Orogen: plagiogranite (970 $\pm 21 \mathrm{Ma}$, zircon SHRIMP U-Pb, NE Jiangxi, Gao et al., 2009; $905 \pm 14 \mathrm{Ma}$, zircon SHRIMP U-Pb, Zhejiang, Ye et al., 2007), andestic rocks (926 \pm $15 \mathrm{Ma}$, zircon SHRIMP U-Pb, Zhejiang, Li et al., 2009), tonalite (913 \pm 15 Ma, zircon SHRIMP U-Pb, Zhejiang, Ye et al., 2007), basalt (904 \pm 8 Ma, zircon SHRIMP U-Pb, Zhejiang, Chen et al., 2009), rhyolite ( $891 \pm 12 \mathrm{Ma}$, zircon SHRIMP U-Pb, Zhejiang, Li et al., 2009), tuff (879 \pm 6 Ma, zircon LA-ICP-MS U-Pb, Jiangxi, Wang et al., 2008), gabbro (875 \pm 8 Ma, zircon LA- 
ICP-MS U-Pb, Jiangxi, Zhang et al., 2013). However, ophiolites crop rarely out in the western Jiangnan Orogen: gabbro (869 \pm 9 Ma, zircon LA-ICP-MS U-Pb, Guangxi, Yao et al., 2016).

Numerous peraluminous granitic plutons crop out along the Jiangnan Orogenic Belt (Fig. 1). Table 1 provides all ages obtained from this type of granitoids with a prominent peak at $830 \pm 10$ Ma though their ages extent from ca. 850 to ca. $805 \mathrm{Ma}$. These granitoids are interpreted as lateto post-collisional plutons (see Section 5.1; Song et al., 2015).

A ca. 800-750 Ma bimodal magmatism composed of basalts and rhyolites has been identified in the eastern Jiangnan Orogenic Belt (Ge et al., 2001; Li et al., 2008b; Wang et al., 2012b). The geochemistry of these rocks confirms the extensional setting of the South China Block since the middle Neoproterozoic. However, the bimodal magmatism is rarely reported in the western Jiangnan Orogenic Belt.

\section{Samples collection and analytical procedures}

\subsection{Sample collection}

We collected sandstone samples from both strata below and above the unconformity in three localities: Fanjingshan (Guizhou Province), Sibao (Guangxi Province) and Madiyi (Hunan Province) (Figs. 1, 2 and 3). GPS locations are provided in Table S1.

\subsection{Analytical procedures}

Whole-rock major element contents were analyzed by ARL-9900 X-ray fluorescence spectrometer (XRF) at the Testing Center of Shandong Bureau of China Metallurgical Geology Bureau. The uncertainties reported in this study are lower than $2 \%$ for major elements. Trace elements and rare earth elements (REE) were measured by ICP-MS (Finnigan Element II) at the Testing Center of Shandong Bureau of China Metallurgical Geology Bureau. International standards (GBW07105 and GBW07122) were used to define the analytical precision and 
accuracy throughout the analytical processes for ICP-MS. The uncertainties are lower than 5\% for trace elements.

Zircons were separated from the crushed rocks using heavy liquid and magnetic techniques and then handpicked under a binocular microscope. The zircon grains were mounted in epoxy resin, and then polished and coated with gold. To reveal the internal textures of zircons, cathodoluminescence (CL) images were obtained using a JEOL JXA8230 electron probe microanalyzer at the Testing Center of Shandong Bureau of China Metallurgical Geology Bureau. The laser ablation (LA)-ICP-MS analysis of zircon U-Pb isotopic compositions was performed at the Testing Center of Shandong Bureau of China Metallurgical Geology Bureau, using a ThermoX2 ICP-MS connected to a GeoLas Pro 193 nm laser ablation system. All analyses were carried out with a spot size of $30 \mu \mathrm{m}$ or $20 \mu \mathrm{m}$ and a laser frequency of $10 \mathrm{~Hz}$. Helium was used as the carrier gas to transport the ablated material. The detailed analytical procedure is described in Liu et al. (2010). All measurements were performed using zircon 91500 as the external standard with a ${ }^{206} \mathrm{~Pb} /{ }^{238} \mathrm{U}$ age of $1065.4 \pm 0.3$ Ma (Wiedenbeck et al., 1995). We calibrated elemental contents with NIST610 as the external standard and ${ }^{29} \mathrm{Si}$ as the internal standard. The $\mathrm{U}-\mathrm{Pb}$ ages were calculated from the raw signal data using the software ICPMSDataCal (ver.8.4). On account of the ${ }^{204} \mathrm{~Pb}$ could not be measured owing to low signal and interference from ${ }^{204} \mathrm{Hg}$ in the gas supply, common lead correction was carried out using the EXCEL program common $\mathrm{Pb}$ correction (Andersen, 2002). For zircons older than $1000 \mathrm{Ma}$, because of large amounts of radiogenic $\mathrm{Pb}$, the ${ }^{207} \mathrm{~Pb} /{ }^{206} \mathrm{~Pb}$ age is more reliable than ${ }^{206} \mathrm{~Pb} /{ }^{238} \mathrm{U}$, whereas for zircons younger than $1000 \mathrm{Ma}$, as a result of the low content of radiogenic $\mathrm{Pb}$ and uncertainty of common $\mathrm{Pb}$ correction, the ${ }^{206} \mathrm{~Pb} /{ }^{238} \mathrm{U}$ age is more reliable. 


\section{Analytical results}

\subsection{Major and trace elements}

The analytical results of major and trace elements of 13 representative samples are given in Table S2. Slate and phyllite of the Sibao Group and its equivalents show high $\mathrm{SiO}_{2}$ (72.2-79.8 wt $\%)$, intermediate $\mathrm{Al}_{2} \mathrm{O}_{3}(6.2-13.1 \mathrm{wt} \%)$. However, sandstone, metapsammite and slate of the Danzhou Group and its equivalents yield lower $\mathrm{SiO}_{2}(66.2-77.1$ wt $\%)$ and higher $\mathrm{Al}_{2} \mathrm{O}_{3}(7.3-$ $16.0 \mathrm{wt} \%$ ). These two suites of strata have similar content in $\mathrm{Fe}_{2} \mathrm{O}_{3}, \mathrm{MgO}$ and $\mathrm{K}_{2} \mathrm{O}$. The most prominent character of all samples analyzed for geochemistry is that they display similar chondrite-normalized steep rare earth element (REE) patterns revealing obvious enrichment in light rare earth element (LREE) with respect to heavy rare earth element (HREE; Fig. 6A). LREE/HREE values range from 6.2 to 16.3 , and $(\mathrm{La} / \mathrm{Yb})_{\mathrm{N}}$ vary from 3.3 to 14.2 with an average of 8.2. All the samples reveal distinct negative Eu anomalies (Eu/Eu* value of 0.31-0.70, with an average of 0.53). On the upper crust normalized spidergrams (Fig. 6B), all samples exhibit strong negative $\mathrm{Ba}, \mathrm{Sr}$ and $\mathrm{Nb}$ anomalies and the enrichment of $\mathrm{Rb}$, Th and $\mathrm{U}$, suggesting that the sedimentary rocks were derived from the upper crustal source (Taylor and McLennan, 1981; Sun and McDonough, 1989).

\subsection{Zircon cathodoluminescence images}

Representative cathodoluminescence (CL) images of detrital zircons of the six samples are shown in Fig. 7. In majority, the zircon grains are subhedral and euhedral, revealing that they are near source accumulation. Most of zircon grains display clear oscillatory zoning with granitic zircon feature, while three of them show broad banded structure with mafic zircon characters $\left(\mathrm{n}^{\circ}\right.$ 1933-12, 1933-32, 1714-32). Some zircon grains reveal thin luminescent overgrowth rims that appear bright in the $\mathrm{CL}$ images, displaying low $\mathrm{Th} / \mathrm{U}$ ratios of $0.06-0.11$ (Table $\mathrm{S} 3$ ) which are 
suggested as formed during metamorphism (Hoskin and Black, 2000; Corfu et al., 2003). Interestingly, this phenomenon is found both within older cores (2529-946 Ma) and younger overgrowth rims (865-852 Ma).

\subsection{Detrital zircon $\mathrm{U}-\mathbf{P b}$ ages}

\subsubsection{Sibao Group and its equivalents}

Two hundreds and sixty-one zircon data yield good concordance (94\%-99\%) (Fig. 8 and Table S3). The Sibao Group and its equivalents reveal one significant peak at $853 \mathrm{Ma}$, one minor peak cluster ranging from $1900 \mathrm{Ma}$ to $1500 \mathrm{Ma}$ and one inconspicuous peak at ca. $2450 \mathrm{Ma}$, with the youngest age at $832 \mathrm{Ma}$ (Fig. 9B).

The one collected in Fanjingshan (1933) yields ages in the range of 2176-834 Ma with a peak at 849 Ma. The ages of samples collected in Madiyi (1400) and Sibao (1714) range in 2645-832 Ma, and 3038-838 Ma, with distinct peaks at $861 \mathrm{Ma}$ and $856 \mathrm{Ma}$, respectively. The peak clusters ranging from ca. 1000 Ma to ca. 870 look like a shoulder, lying behind the prominent peaks, and are remarkable in all of the three plots (Fig. 8).

\subsubsection{Danzhou Group and its equivalents}

Totally, we got 227 zircon ages for the Danzhou Group and its equivalents, most of them are concordant (92\%-99\%) (Fig. 8 and Table S3). In general, the age spectrum shows two obvious peaks at $850 \mathrm{Ma}$ and $795 \mathrm{Ma}$, one minor peak cluster at ca. 1900-1500 Ma, and one minor peak at $2500 \mathrm{Ma}$ as a whole, the relative probability plot reveals a good similarity with that of the Sibao Group and its equivalents except one significant peak at 795 Ma (Fig. 9D). Moreover, there is no detrital zircon age ranging from ca. 832 Ma to ca. 803 Ma recorded in the Danzhou Group and its equivalents (Fig. 9D).

Individually, the sample collected in Fanjingshan (1932) yields ages in the range of 2803- 
$779 \mathrm{Ma}$. As for the samples collected in Madiyi (1399) and Sibao (1714-1), they show ages ranging in 2997-783 Ma and 2562-796 Ma intervals, respectively. Two distinct peaks, ca. 850 Ma and ca. $795 \mathrm{Ma}$, are displayed in the relative probability plot of the sample collected from Fanjingshan and Madiyi (Fig. 8). However, the plot of the sample collected from Sibao reveals a different pattern and presents a significant age cluster at 903-850 Ma, two prominent peaks at $997 \mathrm{Ma}$ and $796 \mathrm{Ma}$, one minor peak clusters at 1790-1617 Ma and one minor peak at $2507 \mathrm{Ma}$ (Fig. 8).

\section{Discussion}

\subsection{Comparison of the age spectra between the Sibao and Danzhou Groups and geological significance of the detrital zircon ages}

The detrital zircon U-Pb age spectra of the Sibao and Danzhou Groups and their equivalents are given in Figs. 8 and 9. In general, the age spectrum of the Sibao Group and its equivalents yields a distinct peak at $853 \mathrm{Ma}$ and an obvious peak cluster ranges in 1000-870 Ma as a shoulder, with two minor peaks at $1700 \mathrm{Ma}$ and $2500 \mathrm{Ma}$ (Fig. 9A). The age spectrum of rocks from the Danzhou Group and its equivalents inherits the features of those of the Sibao Group and its equivalents, but also contains a younger peak at 795 Ma.

Independently, the detrital zircon age spectra of the top sequence of the Sibao Group and its equivalents collected from three localities display a good comparability with a significant peak at ca. $855 \mathrm{Ma}$ and an obvious peak cluster ranging from 1000 to $870 \mathrm{Ma}$. The ages ranging from ca. $1500 \mathrm{Ma}$ to ca. $1000 \mathrm{Ma}$ are rarely recorded except for that of the sample collected from the Sibao area (Fig. 8). In terms of the bottom of the Danzhou Group and its equivalents, the samples collected from Fanjingshan and Madiyi present two similar peaks at ca. $850 \mathrm{Ma}$ and ca. $795 \mathrm{Ma}$. However, the sample collected in the Sibao area presents a more complicated pattern that reveals 
a main peak cluster ranging around 903-850 Ma with two peaks at $997 \mathrm{Ma}$ and $796 \mathrm{Ma}$ as shoulders. The spectra from all three areas also show prominent age peaks ranging from 1790 to $1617 \mathrm{Ma}$ and at $2507 \mathrm{Ma}$. It is worth noting that the detrital zircon age spectrum of the Danzhou Group sample collected from the Sibao area is different with those collected from the Fanjingshan and Madiyi areas, as it displays multiple peaks with respect to the other two. The zircon age distribution pattern of the Sibao sample can be traced in the detrital zircon spectrum of the Cathaysia Block (Fig. 10C). From the geographical point of view, the Sibao area is closer to the collision boundary than the Fanjinshan and Madiyi ones (Fig. 1), therefore, we may infer that the detritus in the Danzhou Group of the Sibao area was partly supplied by the Cathaysia Block.

The various detrital zircon ages have different geological significances. Some xenocrystic zircons dated at ca. 2600-2400 Ma in the lamprophyric and basaltic rocks have been found in Hunan, Hubei and Guizhou provinces, in the eastern and northern Yangtze Block (Zheng et al., 2006; Wang et al., 2012b). Detrital zircons with similar ages have been reported in the areas of Wuyi, southern Jiangxi and northern Guangdong provinces, Cathaysia Block (Gan et al., 1996; Yu et al., 2006, 2009). The minority of detrital zircons dated at ca. $2500 \mathrm{Ma}$ in this study might correspond to the period of global continental growth at the end Archean-early Paleoproterozoic, which was already proposed by Yao et al. (2011). Similarly, the detrital zircon ages at ca. 1900$1500 \mathrm{Ma}$ are interpreted to be linked with the Columbia supercontinent (Rogers and Santosh, 2002; Zhao et al., 2002). The detrital zircons ranging from $1500 \mathrm{Ma}$ to $1000 \mathrm{Ma}$ are abundant in the Cathaysia Block but rare in the Yangtze Block (Fig. 10A), which can be related to the Rodinia supercontinent and Grenville Orogeny ( $\mathrm{Li}$ et al., 2002). However, the detrital zircon spectra of the Yangtze Block and Jiangnan Orogen show a distinct differentiation across the time 
point at $1000 \mathrm{Ma}$ (Fig. 10), suggesting that a gradually enhanced magmatism should have occurred after that time. Besides, igneous rocks dated at ca. 1000-870 Ma are widely reported in the Jiangnan Orogenic Belt (Xin et al., 2017 and references therein), indicating that the Jiangnan region was an active magmatic zone. Based on the geological facts (i.e., ca. 1.0 Ga subduction related arc magmatism, see Section 2.4) and the analysis of detrital zircon age spectra in this study, we suggest that the Paleo-South China Ocean started to subduct at ca. $1000 \mathrm{Ma}$ (Fig. 11). In this study, a few zircons with core-rim structure are observed (Fig. 7), the light luminescence rims suggest a hydrothermal event (Hoskin and Schaltegger, 2003; Dubińska et al., 2004), in the range of 865-852 Ma, which are produced by metamorphism and related to the collision of the Yangtze and Cathaysia blocks. The emplacement of regional numerous S-type granite plutons, dated at 830-820 Ma along the Jiangnan Orogen, formed by the melting of a continental crust. It is widely accepted that the S-type granite is product of the crustal partial melting, and related to a collision, however, it is still questionable whether this type of granite is generated and emplaces in the syn-collision or post-collision setting (Mass et al., 1997; Clemens et al., 2003; Collins and Richard, 2008; Song et al., 2015). Though the generation of crustal partial melting largely depends on the water content in the initial crustal materials, the melting temperature varies with the pressure, i.e. higher pressure versus higher melting temperature. Therefore, it is more difficult to melt crustal material and generate magma in a syn-collision compressive context than in the post-collision decompressive one. Moreover, the transport and intrusion of magma could be less easier in a shortening context than in an extensive one. The S-type granites from the Variscan and Himalayan orogens present good examples of the emplacement mechanism of the acidic magma. The study on the S-type granite from the Sanfang and Yuanbaoshan plutons, localised in the western part of the Jiangnan Orogenic Belt, reveals that the magma was 
generated and emplaced posterior to the main phase of the collision and in the lower stress environment. Consequently, the emplacement of regional numerous S-type granite plutons, dated at 830-820 Ma along the Jiangnan Orogen, produced by the crustal partial melting, implies the ending (or late stage) of the orogeny. Afterwards, the absence of a magmatic activity during the interval of the 820-803 Ma (Fig. 9D) may suggest that the Jiangnan Orogen was in a tectonic quiet period. The newly formed South China block began to rift around 800-780 Ma, marked by the abundant bimodal magmatism (Wang et al., 2007). The youngest zircon, dated at $779 \mathrm{Ma}$, in the bottom of the Danzhou Group may record the starting time of the deposition of the Danzhou Group in the Jiangnan region.

\subsection{Comparison of the detrital zircon age spectra of Neoproterozoic strata in the South}

\section{China Block}

In order to characterize the detrital zircon age spectra originated from the Neoproterozoic strata of the Yangtze Block, Jiangnan Orogen and Cathaysia Block, we collected thousands of available detrital zircon age data (Table S4) from early Neoproterozoic (Sibao Group and its equivalents), middle Neoproterozoic (Danzhou Group and its equivalents) and late Neoproterozoic strata (Sinian and its equivalents, ca. 720-540 Ma, (BGMRGX, 1985; BGMRHN, 1988)) in three regions, mainly including the eastern Yangtze Block (northern Guizhou, northern Hunan and western Hubei provinces), whole Jiangnan Orogen (Anhui, Jiangxi, Hunan, northern Guangxi and eatern Guizhou provinces) and Cathaysia Block (Fujian, Guangdong, southeastern Hunan and southeastern Guangxi provinces) (Fig. 10I).

As shown in Fig. 10, the pattern of the detrital zircon age spectrum of the Jiangnan Orogen is almost consistent with that of the Yangtze Block, but significantly different from that of the Cathaysia Block (Figs. 10A, 10B and 10C). A prominent view shows that both relative 
probability plots of zircon age distribution from the Yangtze Block and Jiangnan Orogen display an increasing trend from $1000 \mathrm{Ma}$ to ca. $850 \mathrm{Ma}$ (Figs. 10E and 10F). However, the contemporaneous peak cluster in the Cathaysia Block seems quite different from the former two (Fig. 10G). In addition, the ca. 1.0 Ga ophiolitic mélange and arc related magmatism heralded an intervening ocean (i.e., Huaiyu marginal sea, Shu et al., 1995, 2019) between the Yangtze and Cathaysia blocks. Consequently, we may qualitatively infer that the Cathaysia Block was not in contact with the Yangtze Block at ca. 1000 Ma (Fig. 11).

S-type granites, dated at ca. 850-820 Ma, are widely distributed in the Jiangnan Orogenic Belt (Shu, 2012; Yao et al., 2014b; Xin et al., 2017 and references therein). However, rare contemporaneous magmatic event is known within the Yangtze and Cathaysia blocks. These plutons formed through the melting of a continental crust emplaced at the end of the Jiangnan collision. Nevertheless, we notice that the zircon age peak cluster from ca. $850 \mathrm{Ma}$ to $820 \mathrm{Ma}$ can be observed in the age spectra of both the Yangtze and Cathaysia blocks (Figs. 10E and 10G). A possible interpretation is that these ca. $850-820$ Ma detrital zircons were derived from the S-type granites in the Jiangnan Orogen. S-type granite indicates the late stage of the Jiangnan Orogeny, thus the collision between the Yangtze and Cathaysia blocks should have occurred before $850 \mathrm{Ma}$. Furthermore, the relative probability plots of zircon age distribution from the Yangtze Block, Jiangnan Orogen and Cathaysia Block show that the proportion of the Jiangnan Orogen is approximately equal to the sum of those of the Yangtze and Cathaysia blocks in the range of ca. $865-820 \mathrm{Ma}$ (Figs. 10D and 10H). This result can be interpreted as the Jiangnan Orogen was the unique source provider for the eastern Yangtze Block and western Cathaysia Block in the period from ca. 865 to 820 Ma. In other words, we propose that the collision between the Yangtze and Cathaysia blocks probably started at ca. $865 \mathrm{Ma}$ and ended at ca. 820 
Ma. Such a 45 Myr orogenic duration is similar with some well known orogenic belts, such as the Variscan and Himalayas. (e.g. Chung et al., 2005; Faure et al., 2008; Charles et al., 2009; Martinez-Catalan et al., 2014).Nevertheless, some researchers proposed that the collision took place after ca. $820 \mathrm{Ma}$, owing to the geochronology result of previously thought subduction related gabbro and diorite (ca. 850-820 Ma) in both the eastern and western parts of the Jiangnan Orogen (Zhou et al., 2009; Liu et al., 2015; Xia et al., 2015; Sun et al., 2017). However, the CL images of the dated zircons show oscillatory zoning (typical feature of acidic magma zircon) rather than broad bands (typical feature of mafic magma zircon) (Wu and Zheng, 2004). In addition, these zircons are anhedral instead of euhedral shaped. Consequently, these zircons cannot be considered as magmatic ones and were probably captured, as xenocrysts from the late to post-orogenic peraluminous granites, which are widely distributed along the Jiangnan orogenic belt, during the mafic magmatism in the Neoproterozoic Nanhua rifting period. Moreover, recent study reveals that the final closure of the Paleo-South China Ocean is unisochronous in the western and eastern parts of the Jiangnan region (Shu et al., 2019), which approaches the understanding of the tectonic evolution of the Jiangnan Orogenic Belt.

\subsection{Significance of the geochemistry and sedimentation record of the Sibao Group}

The Sibao Group and its equivalents are mainly composed of phyllite, slate, greywacke, and low mature arkose. However, the Danzhou and its equivalents, unconformably covering the Sibao Group and its equivalents, consist mainly of a suite of conglomerate, slate, sandstone and carbonate (BGMRAH, 1982; BGMRJX, 1984; BGMRGX, 1985; BGMRHN, 1988). Although the weathering and metamorphism may affect the geochemical character of the source rocks, the immobile elements can be still traced as a provenance indicator (Singh, 2009; Wang et al., 2012a). In the Hf-La/Th plot (Fig. 5A), most samples of the Sibao Group and its equivalents 
cluster around the average compositions of andesite, TTG, felsic volcanic rock and granite, which are the source providers for the Sibao Group and its equivalents (Floyd and Leveridge, 1987). The tonalite-trondhjemite-granite (TTG) crust has been acknowledged as formed in a subduction zone (Senshu et al., 2009; Hoffmann et al., 2012; Zhang and Zhai, 2012). In the plot of tectonic setting discriminant, all the samples of the Sibao Group and its equivalents drop in the active continental margin field (Fig. 5B), suggesting that the sources of Sibao Group and its equivalents were more likely deposited in an active continental margin (Bhatia, 1983). The prominent trace and rare earth elements characters of the Sibao Group and its equivalents show distinct enrichment in light rare earth element (LREE) with respect to heavy rare earth element (HREE), and yield strong negative $\mathrm{Ba}, \mathrm{Sr}$ and $\mathrm{Nb}$ anomalies (Fig. 6). These features suggest that the top sequence of the Sibao Group sediments was derived from an upper crustal source.

Considering the depositional environment of the Sibao Group and its equivalents, there are some controversial issues, such as the time span of the depositional process and the tectonic setting during the accumulation of the Sibao Group and its equivalents.

The majority of researchers acknowledged that the upper limit of the Sibao Group and its equivalents ranges around $835 \mathrm{Ma}$ to $815 \mathrm{Ma}$ (Wang et al., 2010a, 2012a; Zhao and Cawood, 2012; Zhang et al., 2013; Yao et al., 2014a; Su et al., 2018). However, there is no general agreement on the initial time of the sedimentation of the Sibao Group and its equivalents. A school of researchers suggested that the Sibao Group and its equivalents initiate to deposit at around 1.0 Ga according to detrital zircon trace of the Sibao Group and its equivalents (Shu, 2012; Zhao and Cawood, 2012; Yao et al., 2014a). Nevertheless, some authors pointed out that the maximum depositional age of the Sibao Group and equivalents is ca. $870 \mathrm{Ma}$ (Wang et al., 2007; Zhou et al., 2009; Su et al., 2018) by using of the youngest detrital zircon age of the 
"bottom" sequence of the Sibao Group. However, the sampling sites are about 2000 meters above the bottom according to their stratigraphic column. It could be a workable way to trace the bottom depositional age of the Sibao Group and equivalents by analyzing the detrital zircon spectrum. In this study, we propose that the maximum depositional age of the Sibao Group is at ca. $1000 \mathrm{Ma}$, when the detrital zircon spectra become distinct (Figs. 8, 9 and 10B).

Concerning the sedimentation setting of the Sibao Group and its equivalents, most of the researchers hold the view that the Sibao Group and its equivalents were accumulated in a backarc basin (Wang et al., 2010a, 2012a; Shu, 2012; Yao et al., 2014b; Zhang and Wang, 2016), while some others proposed that they were deposited in a foreland basin (Wang et al., 2007; Zhou et al., 2009). In all these tectonic interpretations, they suggested that the collision of the Yangtze and Cathaysia blocks (i.e. the Jiangnan Orogeny) took place after the end of the sedimentation of the Sibao Group and its equivalents.

However, in this study, we propose some new perspectives. As a great number of arc related magmatic rocks are exposed along the Jiangnan Orogen, we argue that the Paleo-South China Ocean started to subduct northwestwards (present coordinates) beneath the Yangtze Block since around 1000 Ma. Combined with the zircon spectra analysis of the Sibao Group and its equivalents, we suggest that the Sibao Group and its equivalents were formed along with the subduction of the Paleo-South China Ocean. Some oceanic crust relics were scratched and involved into the Sibao deposits during the ongoing subduction. Thus, the lower part of the Sibao Group is considered as an accretionary complex. Meanwhile, the mafic rocks related with arc magmatism intruded into the Sibao Group and its equivalents (Zhou et al., 1989; Chen et al., 2009; Zhang et al., 2013; Yao et al., 2014b, 2016; Fig. 1). Associated with the analysis of the geochemistry, we propose that in the subduction period from $1.0 \mathrm{Ga}$ to $865 \mathrm{Ma}$ (see Sections 5.1 
and 5.2), the Sibao Group and its equivalents were deposited in an active continental margin zone (Fig. 11).

The youngest detrital zircon is dated around 830-820 Ma in the Sibao Group and its equivalents (Su et al., 2018 and references therein, and this study), which is consistent with the geological fact that the Sibao Group and its equivalents are intruded by the ca. 830-820 Ma Stype granitic plutons in the Jiangnan Orogen.

Therefore, we suggest that the tectonic setting of the sedimentation of the Sibao Group and its equivalents can be divided into two stages. Firstly, at ca. 1000-865 Ma, it deposited in an active continental margin. Secondly, around 865-820 Ma, after the collision of the Yangtze and Cathaysia blocks, the Sibao Group and its equivalents were accumulated during the crustal thickening. By an $\varepsilon H f(t)$ study in the Anleilin and Xiushui formations (equivalent to the Sibao Group), Li et al. (2016b) showed that the negative $\varepsilon H f(t)$ values increase along the stratigraphic sequence from the bottom to the top, indicating that the Sibao Group and its equivalents received more and more crustal derived materials during its deposition in the early Neoproterozoic, which implies that the Sibao Group and its equivalents had experienced a tectonic setting transition from an active continental margin to continental collision. In other words, the Sibao Group and its equivalents have recorded both the subduction and collision events.

Afterwards, the Danzhou Group and its equivalents began to accumulate at ca. 780 Ma. The bottom sequence inherited the bulk geochemical signature of the Sibao Group and its equivalents (Figs. 5 and 6), except that the rocks from the Danzhou and its equivalents present higher $\mathrm{Al}_{2} \mathrm{O}_{3}$ and lower $\mathrm{SiO}_{2}$ contents than those from the Sibao Group and its equivalents probably owing to the mechanical sorting and chemical changes related to transportation (Fralick and Kronberg, 1997). 


\subsection{Geodynamic evolution of the South China Block in the Early Neoproterozoic}

The Jiangnan Orogenic Belt was built up due to the convergence of the Paleo-South China Ocean and the collision between the Yangtze and Cathaysia blocks (Shu, 2012; Charvet, 2013), but its geodynamic evolution process is still debated. In this study, according to the geological evidence, zircon geochronology and whole rock geochemical study of the Sibao and Danzhou Groups and their equivalents, a possible spatial and temporal tectonic evolution model of the Early Neoproterozoic geological events can be suggested in the following.

As the detrital zircon spectra show a distinct differentiation across $1000 \mathrm{Ma}$ (Fig. 10), it may suggest that a significant magmatism should have occurred after that time. The ophiolitic mélange, gabbro and oceanic plagiogranite dated at ca. $1000 \mathrm{Ma}$ in the eastern part of the Jiangnan Orogen indicates that the subduction of the Paleo-South China Ocean took probably place after that time (Zhou et al., 1989; Chen et al., 1991; Li et al., 1994; Gao et al., 2009; Wang et al., 2015). The mafic rocks dated at 935 Ma together with the volcanic rocks ranging in $880-$ $870 \mathrm{Ma}$ are arc related (Yao et al., 2014b and references therein; Xin et al., 2017 and references therein), as well as the ca. 869 Ma ophiolitic gabbro (Yao et al., 2016) and ca. 866 Ma blueschist (Shu et al., 1994), indicating that the subduction of the Paleo-South China Ocean was ongoing during the ca. 1000-865 Ma. In addition, the spectra analysis of detrital zircon age in this study points out that the subduction of the Paleo-South China Ocean probably started at ca. $1000 \mathrm{Ma}$ and ended at ca. 865 Ma. During this period, the Sibao Group and its equivalents were accumulated in the active continental margin setting (Fig. 11).

Afterwards, the Yangtze and Cathaysia blocks began to collide, the changes in temperature and fluid property possibly resulted in the metamorphism in the zircon which are traced at 865$852 \mathrm{Ma}$ in this study. Abundant $830-820$ Ma peraluminous late orogenic granites indicate the 
ending of the Jiangnan Orogeny. In the period of ca. 865-820 Ma, the upper part of the Sibao Group and its equivalents were deposited in a syn-collisional setting (Fig. 11).

The evidence that rare magmatic imprint was traced in the ca. 820-800 Ma period may suggest that the Jiangnan Orogenic Belt was, at that time, probably situated in a tectonically quiet period. Then, in the ca. 800-760 Ma period, the Nanhua rifting was accompanied by both A-type granites plutonism and mafic intrusive rocks (Li et al., 2008b; Wang et al., 2012b). The unconformity between the Sibao Group (and its equivalents) and Danzhou Group (and its equivalents) marks the initial time of the Nanhua rifting in the Jiangnan Orogen area. The youngest zircon age dated at ca. $780 \mathrm{Ma}$ in the bottom sequence of the Danzhou Group (and its equivalents) suggests that the Danzhou Group and its equivalents started their deposition at that time.

\section{Conclusions}

This study aims to explore the collision of the Yangtze and Cathaysia blocks. We have carried out detrital zircon dating and geochemistry study near the Neoproterozoic unconformity in three distinct localities, and synthesized studies by integrating the new and previous data from the Jiangnan Orogen, the Yangtze and Cathaysia blocks, to further understand the Neoproterozoic tectonic evolution of the Jiangnan Orogenic Belt.

Six sedimentary samples yield detrital zircon with U-Pb ages ranging from $779 \pm 16$ Ma to $3006 \pm 36 \mathrm{Ma}$, with a prominent peak at ca. $852 \mathrm{Ma}$. The youngest ages of $832 \pm 11 \mathrm{Ma}$ and 779 \pm 16 Ma are revealed for the underlying Sibao and overlying Danzhou Groups, respectively. Geochemistry study reveals that the sources of the Sibao Group were derived from the upper crustal material with active continental marginal affinity, and the Danzhou Group inherits the 
geochemical signature of the Sibao Group. The Yangtze, Jiangnan and Cathaysia regions have a good consistency since ca. $865 \mathrm{Ma}$ from the synthesized analysis of the detrital zircon age relative probability plots.

Integrating the new results in the detrital zircon dating, geology and geochemistry from three localities in the western part of the Jiangnan Orogen, and previous geochronology data from the Yangtze, Jiangnan and Cathaysia regions, we can conclude the following main results from this study:

(1) The subduction of the Paleo-South China Ocean started at ca. $1000 \mathrm{Ma}$ and ended at ca. $865 \mathrm{Ma}$;

(2) The Jiangnan Orogenic Belt was built up due to the assembly of the Yangtze and Cathaysia blocks between ca. 865 and $820 \mathrm{Ma}$;

(3) The deposition of the Sibao Group lasted from ca. 1000 Ma to $820 \mathrm{Ma}$;

(4) The angular unconformity between the Sibao and Danzhou Groups could take place at ca. $820-800$ (or 780) Ma;

(5) The Danzhou Group and its equivalents began to deposit since ca. $780 \mathrm{Ma}$ in the western Jiangnan Orogen area.

\section{Acknowledgments}

We wish to express our appreciation to Lin P.J. for the help during the work of zircon dating and geochemistry analysis. This study is supported by National Fundamental Research Program of China (973 Program, No. 2012CB416701) and National Natural Science Foundation of China (Nos. 41772204, 41572200). 


\section{References}

Andersen, T., 2002. Correction of common $\mathrm{Pb}$ in $\mathrm{U}-\mathrm{Pb}$ analyses that do not report ${ }^{204} \mathrm{~Pb}$.

Chemical Geology 192, 59-79. doi:10.1016/S0009-2541(02)00195-X

BGMRAH (Bureau of Geology and Mineral Resources of Anhui Province), 1982. Regional Geology of Anhui Province [in Chinese with English Abstract]. Beijing, Geological Publishing House, 715p.

BGMRFJ (Bureau of Geology and Mineral Resources of Fujian Province), 1985. Regional Geology of Fujian Province [in Chinese with English Abstract]. Beijing, Geological Publishing House, 564p.

BGMRGX (Bureau of Geology and Mineral Resources of Guangxi Province), 1985. Regional Geology of Guangxi Autonomous Region [in Chinese with English Abstract]. Beijing, Geological Publishing House, 853p.

BGMRGZ (Bureau of Geology and Mineral Resources of Guizhou Province), 1984. Regional Geology of Guizhou Province [in Chinese with English Abstract]. Beijing, Geological Publishing House, 698p.

BGMRHN (Bureau of Geology and Mineral Resources of Hunan Province), 1988. Regional Geology of Hunan Province [in Chinese with English Abstract]. Beijing, Geological Publishing House, 664p.

BGMRJX (Bureau of Geology and Mineral Resources Jiangxi Province), 1984. Regional Geology of Jiangxi Province [in Chinese with English Abstract]. Beijing, Geological Publishing House, 725p. 
BGMRZJ (Bureau of Geology and Mineral Resources Jiangxi Province), 1989. Regional Geology of Jiangxi Province [in Chinese with English Abstract]. Beijing, Geological Publishing House, 575p.

Bhatia, M.R., 1983. Plate tectonics setting of sandstones and geochemical composition of sandstones. Journal of Geology 91, 611-627. doi:10.1086/628815

Charles, N., Faure, M., Chen, Y., 2009. The Montagne Noire migmatitic dome emplacement (French Massif Central): new insights from petrofabric and AMS studies. Journal of Structural Geology 31, 1423-1440. doi:10.1016/j.jsg.2009.08.007

Charvet, J., 2013. The neoproterozoic-early paleozoic tectonic evolution of the South China Block: an overview. Journal of Asian Earth Sciences 74, 198-209. doi:10.1016/j.jseaes.2013.02.015

Chen, J.F., Foland, K.A., Xing, F., Xu, X., Zhou, T., 1991. Magmatism along the southeastern margin of the Yangtze block: Precambrian collision of the Yangtze and Cathaysia block of China. Geology 19, 815-818. doi:10.1130/0091-7613(1991)0192.3.CO;2

Chen, Z.H., Xing, G.F., Guo, K.Y., Dong, Y.G., Chen, R., Zeng, Y., Li R.M., He, Z.Y., Zhao. L., 2009. Petrogenesis of the Pingshui keratophyre from Zhejiang: zircon U-Pb age and $\mathrm{Hf}$ isotope constraints [in Chinese with English abstract]. Chinese Science Bulletin 54, 610617. doi:10.1007/s11434-009-0081-y

Chung, S.L., Chu. M.F., Zhang, Y.Q., Xie. Y.W., Lo, Q.H., Lee, T.Y., Lan, C.Y., Li, X.H., Zhang, Q., Wang, Y.Z., 2005. Tibetan tectonic evolution inferred from spatial and temporal variations in post-collisional magmatism. Earth Science Reviews 68, 173-196. doi:10.1016/j.earscirev.2004.05.001 
Clemens, J.D., 2003. S-type granitic magmas-petrogenetic issues, models and evidence. Earth Science Reviews 61(1), 1-18. doi:10.1016/S0012-8252(02)00107-1

Collins, W.J., Richards, S.W., 2008. Geodynamic significance of S-type granites in circumPacific orogens. Geology 36(7), 559-562. doi:10.1130/G24658A.1

Corfu, F., Hanchar, J.M., Hoskin, P.W.O., Kinny, P., 2003. Atlas of zircon textures. Reviews in Mineralogy and Geochemistry 53, 469-500. doi:10.2113/0530469

Dubińska, E., Bylina, P., Kozłowski, A., Dörr, W., Nejbert, K., Schastok, J., Kulicki, C., 2004. $\mathrm{U}-\mathrm{Pb}$ dating of serpentinization: hydrothermal zircon from a metasomatic rodingite shell (Sudetic ophiolite, SW Poland). Chemical Geology 203, 183-203. doi:10.1016/j.chemgeo.2003.10.005

Faure, M., Bé Mézème, E., Cocherie, A., Rossi, P., Chemenda, A., Boutelier, D., 2008. Devonian geodynamic evolution of the Variscan Belt, insights from the French Massif Central and Massif Armoricain. Tectonics 27. doi:10.1029/2007tc002115

Faure, M., Shu, L.S., Wang, B., Charvet, J., Choulet, F., Monié, P., 2009. Intracontinental subduction: a possible mechanism for the Early Palaeozoic Orogen of SE China. Terra Nova 21, 360-368. doi:10.1111/j.1365-3121.2009.00888.x

Floyd, P., Leveridge, B., 1987. Tectonic environment of the Devonian Gramscatho basin, south Cornwall: framework mode and geochemical evidence from turbiditic sandstones. Journal of the Geological Society [London] 144, 531-540. doi:10.1144/gsjgs.144.4.0531

Fralick, P.W., Kronberg, B.I., 1997. Geochemical discrimination of clastic sedimentary rock sources. Sedimentary Geology 113, 111-124. doi:10.1016/S0037-0738(97)00049-3 
Gan, X.C., Zhao, F.Q., Jin, W.S., Sun, D.Z., 1996. The U-Pb ages of early Proterozoic-Archean zircons captured by igneous rocks in Southern China [In Chinese with English abstract]. Geochimica 25, 112-119.

Gao, J., Klemd, R., Long, L.L., Xiong, X.M., Qian, Q., 2009. Adakitic signature formed by ractional crystallization: An interpretation for the Neo-Proterozoic meta-plagiogranites of the NE Jiangxi ophiolitic mélange belt, South China. Lithos 110, 277-293. doi:10.1016/j.lithos.2009.01.009

Ge, W.C., Li, X.H., Li, Z.X., Zhou, H.W., 2001. Mafic intrusions in Longsheng area: age and its geological implications [in Chinese with English abstract]. Chinese Journal of Geology 36, $112-118$.

Greentree, M.R., Li, Z.X., Li, X.H., Wu, H.C., 2006. Late Mesoproterozoic to earliest Neoproterozoic basin record of the Sibao orogenesis in west South China and relationship to the assembly of Rodinia. Precambrian Research 151, 79-100. doi:10.1016/j.precamres.2006.08.002

Guo, L.H., Gao, R., 2018. Potential-field evidence for the tectonic boundaries of the central and western Jiangnan belt in South China. Precambrian Reseach 309, 45-55. doi:10.1016/j.precamres.2017.01.028

Guo, L.Z., Shi, Y.S., Ma, R.S., Dong, H.G., Yang, S.F., 1989. The pre-Devonian tectonic patterns and evolution of south China. Journal of Southeast Asian Earth Sciences 3, 87-93. doi:10.1016/0743-9547(89)90012-3

Hoffmann, J.E., Münker, C., Nagel, T.J., Næraa, T., Polat, A., Rosing, M.T., 2012. The tholeiiteTTG connection during Eoarchean crust formation in Isua, southern West Greenland: the role of subduction processes. EGU General Assembly Conference, Abstracts 14, p.8217. 
Hoskin, P.W.O., Black, L.P., 2000. Metamorphic zircon formation by solid state recrystallization of protolith igneous zircon. Journal of Metamorphic Geology 18, 423-439. doi:10.1046/j.1525-1314.2000.00266.x

Hoskin, P.W.O., Schaltegger, U., 2003. The composition of zircon and igneous and metamorphic petrogenesis. Reviews in mineralogy and geochemistry 53, 27-62. doi:10.2113/0530027

Li, J.H., Dong, S.W., Zhang, Y.Q., Zhao, G.C,, Johnston, S.T., Cui, J.J., Xin, Y.J., 2016a. New insights into Phanerozoic tectonics of south China: part 1, polyphase deformation in the Jiuling and Lianyunshan domains of the central Jiangnan Orogen. Journal of Geophysical Research: Solid Earth 121 (4), 3048-3080. doi:10.1002/2015jb012778

Li, J.Y., Wang, X.L., Zhang, F.F., Zhou, X.H., Shu, X.J., 2016b. A rhythmic source change of the Neoproterozoic basement meta-sedimentary sequences in the Jiangnan Orogen: Implications for tectonic evolution on the southeastern margin of the Yangtze block. Precambrian Research 280,46-60. doi:10.1016/j.precamres.2016.04.012

Li, L.M., Lin, S.F., Xing, G.F., Jiang, Y., Xia, X.P., 2018. Geochronology and geochemistry of volcanic rocks from the Jingtan Formation in the eastern Jiangnan Orogen, South China: constraints on petrogenesis and tectonic implications. Precambrian Research 309, 166-180. doi:10.1016/j.precamres.2017.02.012

Li, W.X., Li, X.H., Li, Z.X., Lou, F.S., 2008a. Obduction-type granites within the NE Jiangxi Ophiolite: Implications for the final amalgamation between the Yangtze and Cathaysia Blocks. Gondwana Research 13, 288-301. doi:10.1016/j.gr.2007.12.010

Li, X.H., Zhou, G., Zhao, J., Fanning, C.M., Compston, W., 1994. SHRIMP ion microprobe zircon $\mathrm{U}-\mathrm{Pb}$ age of the NE Jiangxi ophiolite and its tectonic implications [in Chinese with English abstract]. Geochimica (Beijing) 23, 125-131. doi:10.1007/BF02838521 
Li, X.H., Li, Z.X., Ge, W., Zhou, H., Li, W., Liu, Y., Wingate, M.T.D., 2003. Neoproterozoic granitoids in South China: crustal melting above a mantle plume at ca. 825Ma?. Precambrian Research 122, 45-83. doi:10.1016/S0301-9268(02)00207-3

Li, X.H., Li, W.X., Li, Z.X., Liu, Y., 2008b. 850-790 Ma bimodal volcanic and intrusiverocks in northern Zhejiang, South China: a major episode of continental rift magmatism during the breakup of Rodinia. Lithos 102, 341-357. doi:10.1016/j.lithos.2007.04.007

Li, X.H., Li, W.X., Li, Z.X., Lo, C.H., Wang, J., Ye, M.F., Yang, Y.H., 2009. Amalgamation between the Yangtze and Cathaysia blocks in South China: Constraints from SHRIMP U$\mathrm{Pb}$ zircon ages, geochemistry and $\mathrm{Nd}-\mathrm{Hf}$ isotopes of the Shuangxiwu volcanic rocks. Precambrian Research 174, 117-128. doi:10.1016/j.precamres.2009.07.004

Li, X.H., Li, Z.X., Li, W.X., 2014. Detrital zircon U-Pb age and Hf isotope constrains on the generation and reworking of Precambrian continental crust in the Cathaysia Block, South China: A synthesis. Gondwana Research 25, 1202-1215. doi:10.1016/j.gr.2014.01.003

Li, Z.X., Li, X.H., Zhou, H., Kinny, P.D., 2002. Grenville-aged continental collision in South China: new SHRIMP U-Pb zircon results and implications for Rodinia configuration. Geology 30, 163-166. doi:10.1130/0091-7613(2002)0302.0.CO;2

Li, Z.X., Wartho, J.A., Occhipinti, S., Zhang, C.L., Li, X.H., Wang, J., Bao, C.M., 2007. Early history of the eastern Sibao Orogen (South China) during the assembly of Rodinia: New mica ${ }^{40} \mathrm{Ar} /{ }^{39} \mathrm{Ar}$ dating and SHRIMP $\mathrm{U}-\mathrm{Pb}$ detrital zircon provenance constraints. Precambrian Research 159, 79-94. doi:10.1016/j.precamres.2007.05.003

Liu, Y.S., Gao, S., Hu, Z.C., Gao, C.G., Zong, K.Q., Wang, D.B., 2010. Continental and oceanic crust recycling-induced melt-peridotite interactions in the trans-north china orogen: $\mathrm{U}-\mathrm{Pb}$ dating, Hf isotopes and trace elements in zircons from mantle xenoliths. Journal of 
Petrology 51, 537-571. doi:10.1093/petrology/egp082

Liu, Z., Jiang, Y.H., Wang, G.C., Ni, C.Y., Qing, L., Zhang, Q., 2015. Middle Neoproterozoic ( $\sim 845 \mathrm{Ma}$ ) continental arc magmatism along the northwest side of the Jiangshan-Shaoxing suture, South China: geochronology, geochemistry, petrogenesis and tectonic implications. Precambrian Research 268, 212-226. doi:10.1016/j.precamres.2015.07.013

Maas, R., Nicholls, I.A., Legg, C., 1997. Igneous and metamorphic enclaves in the S-type Deddick Granodiorite, Lachlan Fold Belt, SE Australia: Petrographic, Geochemical and NdSr Isotopic Evidence for Crustal Melting and Magma Mixing. Journal of Petrology 38(7), 815-841. doi:10.1093/petrology/38.7.815

Martinez-Catalan, J.R., Rubio Pascual, F.J., Díez Montes A., Díez Fernández, R., Gómez Barreiro, J., Dias Da Silva, I., Clavijo, E.G., Ayarza, P., E. Alcock, J., 2014. The late Variscan HT/LP metamorphic event in NW and central Iberia: Relationships with crustal thickening, extension, orocline development, and crustal evolution. London, Geological Society [London] Special Publications 405, 225-247. doi:10.1144/SP405.1

Rogers, J.J.W., Santosh, M., 2002. Configuration of Columbia, a Mesoproterozoic Supercontinent. Gondwana Research 5, 5-22. doi:10.1016/S1342-937X(05)70883-2

Senshu, H., Maruyama, S., Rino, S., Santosh, M., 2009. Role of tonalite-trodhjemite-granite (TTG) crust subduction on the mechanism of supercontinent breakup. Gondwana Research 15, 433-442. doi:10.1016/j.gr.2008.12.008

Shu, L.S., 2012. An analysis of principal features of tectonic evolution in South China Block [in Chinese with English abstract]. Geological Bulletin of China 31, 1035-1053. doi:10.1007/s11783-011-0280-z 
Shu, L.S., Zhou, G.Q., Shi, Y.S., Yin, J., 1994. Study on the high pressure metamorphic blueschist and its Late Proterozoic age in the Eastern Jiangnan belt. Chinese Science Bulletin 39, 1200-1204. doi:10.1007/BF01067541

Shu, L.S., Shi, Y.S., Guo, L.Z., Charvet, J., Sun, Y., 1995. Plate Tectonic Evolution and the Kinematics of Collisional Orogeny in the Middle Jiangnan, Eastern China [in Chinese with English abstract]. Nanjing, Publishing House of Nanjing University, 174p.

Shu, L.S., Charvet, J., 1996. Kinematic and geochronology of the Proterozoic DongxiangShexian ductile shear zone (Jiangnan region), South China. Tectonophysics 267, 291-302. doi:10.1016/S0040-1951(96)00104-7

Shu, L.S., Faure, M., Jiang, S., Yang, Q., Wang, Y., 2006. SHRIMP zircon U-Pb age, litho and biostratigraphic analyses of the Huaiyu Domain in South China. Episodes 29, 244-252.

Shu, L.S., Jahn, B.M., Charvet, J., Santosh, M., Wang, B., Xu, X.S., Jiang, S.Y., 2014. Early Paleozoic depositional environment and intracontinental orogeny in the Cathaysia Block (South China): implications from stratigraphic, structural, geochemical and geochronologic evidence. American Journal of Science 314, 154-186. doi:10.2475/01.2014.00

Shu, L.S., Wang, B., Cawood, P.A., Santosh, M., Xu, Z.Q., 2015. Early Paleozoic and Early Mesozoic intraplate tectonic and magmatic events in the Cathaysia Block. South China. Tectonics 34, 1600-1621. doi:10.1002/2015TC003835

Shu, L.S., Wang, J.Q., Yao, J.L., 2019. Tectonic evolution of the eastern Jiangnan region, South China: New findings and implications on the assembly of the Rodinia supercontinent. Precambrian Research 322, 42-65. doi:10.1016/j.precamres.2018.12.007 
Singh, P., 2009. Major, trace and REE geochemistry of the Ganga River sediments: Influence of provenance and sedimentary processes. Chemical Geology 266, 242-255. doi:10.1016/j.chemgeo.2009.06.013

Song, S.G., Wang, M.J., Wang, C., Niu, Y.L., 2015. Magmatism during continental collision, subduction, exhumation and mountain collapse in collisional orogenic belts and continental net growth: A perspective. Science China: Earth Sciences 58, 1284-1304. doi: $10.1007 / \mathrm{s} 11430-015-5102-\mathrm{x}$

Su, H.M., Jiang, S.Y., Mao, J.W., Zhang, D.Y., Wu, X.K., Qin, H.F., 2018. U-Pb Ages and LuHf Isotopes of Detrital Zircons from Sedimentary Units across the Mid-Neoproterozoic Unconformity in the Western Jiangnan Orogen of South China and Their Tectonic Implications. Journal of Geology 126, 207-228, doi:10.1086/694907

Sun, J.J., Shu, L.S., Santosh, M., Wang, L.S., 2017. Neoproterozoic tectonic evolution of the Jiuling terrane in the central Jiangnan orogenic belt (South China): Constraints from magmatic suites. Precambrian Research 302, 279-297. doi:10.1016/j.precamres.2017.10.003

Sun, S.S., McDonough, W.F., 1989. Chemical and isotopic systematics of oceanic basalts: implication for mantle composition and processes. Geological Society of London 42, 313345. doi:10.1144/GSL.SP.1989.042.01.19

Taylor, S.R., McLennan, S.M., 1981. The composition and evolution of the continental crust: rare earth element evidence from sedimentary rocks [and discussion]. Philosophical Transactions of the Royal Society A 301, 381-399. doi:10.1109/WFCS.2015.7160546

Wang, J., Li, Z.X., 2003. History of Neoproterozoic rift basins in South China: implications for Rodinia break-up. Precambrian Research 122, 141-158. doi:10.1016/S03019268(02)00209-7 
Wang, M., Dai, C.G., Wang, X.H., Chen, J.S., Ma, H.Z., 2011. In-situ zircon geochronology and Hf isotope of muscovite-bearing leucogranites from Fanjingshan, Guizhou Province, and constraints on continental growth of the Southern China block [in Chinese with EnglishAbstract]. Earth Science Frontiers 18, 213-223. doi:10.1007/s11442-011-0836-7

Wang, W., Wang, F., Chen, F., Zhu, X., Xiao, P., Siebel, W., 2010a. Detrital zircon ages and HfNd isotopic composition of Neoproterozoic sedimentary rocks in the Yangtze block: constraints on the deposition age and provenance. The Journal of Geology 118, 79-94. doi:10.1086/648533

Wang, W., Zhou, M.F., Yan, D.P., Li, J.W., 2012a. Depositional age, provenance, and tectonic setting of the Neoproterozoic Sibao Group, southeastern Yangtze block, South China. Precambrian Research 192, 107-124. doi:10.1016/j.precamres.2011.10.010

Wang, X.L., Zhou, J.C., Qiu, J.S., Zhang, W.L., Liu, X.M., Zhang, G.L., 2006. LA-ICP-MS U$\mathrm{Pb}$ zircon geochronology of the Neoproterozoic igneous rocks from NorthernGuangxi Province, South China: implications for the tectonic evolution. Precambrian Research 145, 111-130. doi:10.1016/j.precamres.2005.11.014

Wang, X.L., Zhou, J.C., Griffin, W.L., Wang, R.C., Qiu, J.S., O’Reilly, S.Y., Xu, X.S., Liu, X.M., Zhang, G.L., 2007. Detrital zircon geochronology of Precambrian basement sequences in the Jiangnan orogen: dating the assembly of the Yangtze and Cathaysia Blocks. Precambrian Research 159, 117-131. doi:10.1016/j.precamres.2007.06.005

Wang, X.L., Zhao, G.C., Zhou, J.C., Liu, Y.S., Hu, J., 2008. Geochronology and Hf isotopes of zircon from volcanic rocks of the Shuangqiaoshan Group, South China: Implications for the Neoproterozoic tectonic evolution of the eastern Jiangnan orogen. Gondwana Research 14, 355-367. doi:10.1016/j.gr.2008.03.001 
Wang, X.L., Shu, L.S., Xing, G.F., Zhou, J.C., Tang, M., Shu, X.J., Qi, L., Hu, Y.H., $2012 b$. Post-orogenic beltic extension in the eastern part of the Jiangnan Orogenic belt: evidence from ca 800-760 Ma volcanic rocks. Precambrian Research 222-223, 404-423. doi:10.1016/j.precamres.2011.07.003

Wang, X.S., Gao, J., Klemd, R., Jiang, T., Zhai, Q.G., Xiao, X.C., Liang X.Q., 2015. Early Neoproterozoic multiple arc-back-arc system formation during subduction-accretion processes between the Yangtze and Cathaysia blocks: New constraints from the suprasubduction zone NE Jiangxi ophiolite (South China). Lithos 236-237, 90-105. doi:10.1016/j.lithos.2015.08.007

Wiedenbeck, M., Alle, P., Corfu, F., Griffin, W.L., Meier, M., Oberli, F., Quadt, A.V., Roddick, J.C., Spiegel. W., 1995. Three natural zircon standards for U-Th-Pb, Lu-Hf, trace element and REE analyses. Geostandards Newsletter 19, 1-23. doi:10.1111/j.1751908X.1995.tb00147.x

Wu, R.X., Zheng, Y.F., Wu, Y.B., Zhao, Z.F., Zhang, S.B., Liu, X.M., Wu, F.Y, 2006. Reworking of juvenile crust: Element and isotope evidence from Neoproterozoic granodiorite in South China. Precambrian Research, 146, 179-212. doi:10.1016/j.precamres.2006.01.012

Wu, Y.B., Zheng, Y.F., 2004. Zircon genetic mineralogy study and constraint on the interpretation of the U-Pb age. Chinese Science Bulletin 16, 1589-1604.

Wu, T., Zhou, J.X., Wang, X.C., Li, W.X., Wilde, S.A., Sun, H.R.,Wang, J.S., Li, Z., 2018. Identification of ca. $850 \mathrm{Ma}$ high-temperature strongly peraluminous granitoids in southeastern Guizhou Province, South China: A result of early extension along the southern 
margin of the Yangtze Block. Precambrian Research, 308, 18-34. doi:10.1016/j.precamres.2018.02.007

Xia, Y., Xu, X.S., Zhao, G.C., Liu, L., 2015. Neoproterozoic active continental margin of the Cathaysia block: Evidence from geochronology, geochemistry, and $\mathrm{Nd}-\mathrm{Hf}$ isotopes of igneous complexes. Precambrian $\quad$ Research 195-216. doi:10.1016/j.precamres.2015.08.006

Xia, Y., Xu, X.S., Niu, Y.L., Liu, L., 2018. Neoproterozoic amalgamation between Yangtze and Cathaysia blocks: The magmatism in various tectonic settings and continent-arc-continent collision. Precambrian Research 309, 56-87. doi:10.1016/j.precamres.2017.02.020

Xin, Y., Li, J., Dong, S., Zhang, Y., Wang, W., Sun, H., 2017. Neoproterozoic post-collisional extension of the central Jiangnan Orogen: Geochemical, geochronological, and Lu-Hf isotopic constraints from the ca. 820-800 Ma magmatic rocks. Precambrian Research 294, 91-110. doi:10.1016/j.precamres.2017.03.018

Xu, X.B., Zhang, Y.Q., Shu, L.S., Jia, D., Wang, R.R., Xu, H.Z., 2010. Precambrian geochronology and stratigraphy in the Wuyishan area, South China [in Chinese with English abstract]. Journal of Stratigraphy 34, 254-267. doi:10.1017/S0004972710001772

Xu, X.B., Li, Y., Tang, S., Xue, D.J., Zhang, Z.J., 2015. Neoproterozoic to early Paleozoic polyorogenic deformation in the southeastern margin of the Yangtze block: constraints from structural analysis and 40Ar/39Ar geochronology. Journal of Asian Earth Sciences 98, 141151. doi:10.1016/j.jseaes.2014.11.015

Xue, H.M., Ma, F., Song, Y.Q., Xie, Y.P., 2010. Geochronology and geochemisty of the Neoproterozoic granitoid association from eastern segment of the Jiangnan orogen, China: Constraints on the timing and process of amalgamation between the Yangtze and Cathaysia 
blocks [in Chinese with English abstract]. Acta Geologica Sinica 26, 3215-3244. doi:10.1130/G30929C.1

Yan, C.L., Shu, L.S., Santosh, M., Yao, J.L., Li, J.Y., Li, C., 2015. The Precambrian tectonic evolution of the western Jiangnan Orogen and western Cathaysia Block: Evidence from detrital zircon age spectra and geochemistry of clastic rocks. Precambrian Research 268, 33-60. doi:10.1016/j.precamres.2015.07.002

Yao, J.L., Shu, L.S., Santosh, M., 2011. Detrital zircon U-Pb geochronology, Hf-isotopes and geochemistry-new clues for the Precambrian crustal evolution of Cathaysia block South China. Gondwana Research 20, p. 553-567. doi:10.1016/j.gr.2011.01.005

Yao, J.L., Shu, L.S., Santosh, M., Xu, Z.Q., 2014a. Palaeozoic metamorphism of the Neoproterozoic basement in NE Cathaysia: zircon U-Pb ages, $\mathrm{Hf}$ isotope and whole-rock geochemistry from the Chencai Group. Journal of the Geological Society [London] 171, 281-297. doi:10.1144/jgs2013-036

Yao, J.L., Shu, L.S., Santosh, M., Zhao, G.C., 2014b. Neoproterozoic arc-related maficultramafic rocks and syn-collision granite from the western segment of the Jiangnan Orogen, South China: constraints on the Neoproterozoic assembly of the Yangtze and Cathaysia Blocks. Precambrian Research 243, 39-62. doi:10.1016/j.precamres.2013.12.027

Yao, J.L., Cawood, P.A., Shu, L.S., Santosh, M., Li, J.Y., 2016. An early Neoproterozoic accretionary prism ophiolitic Mélange from the Western Jiangnan Orogenic Belt, South China. Journal of Geology 124, 587-601. doi:10.1086/687396

Ye, M.F., Li, X.H., Li, W.X., Liu, Y., Li, Z.X., 2007. SHRIMP zircon U-Pb geochronological and whole-rock geochemical evidence for an early Neoproterozoic Sibaoan magmatic arc 
along the southeastern margin of the Yangtze Block. Gondwana Research 12, 144-156. doi:10.1016/j.gr.2006.09.001

Yu, J.H., Wang, L.J., Zhou, X.M., Jiang, S.Y., Wang, R.C., Xu, X.S., Qiu, J.S, 2006. Compositions and formation history of the basement metamorphic rocks in northeastern Guangdong province [In Chinese with English abstract]. Earth Science 31, 38-48. doi:10.1007/s11442-006-0415-5

Yu, J.H., Wang, L.J., O'Reilly, S.Y., Griffin, W.L., Zhang, M., Li, C.Z., Shu, L.S., 2009. A Paleoproterozoic orogeny recorded in a long-lived cratonic remnant (Wuyishan terrane), eastern Cathaysia Block, China. Precambrian Research 174, 347-363. doi:10.1016/j.precamres.2009.08.009

Zhang, C.L., Santosh, M., Zou, H.B., Li, H.K., Huang, W.C., 2013. The Fuchuan ophiolite in Jiangnan Orog Geochemistry, zircon $\mathrm{U}-\mathrm{Pb}$ geochronology, Hf isotope, implications for the Neoproterozoic assembly of South, China. Lithos 179, 263-274. doi:10.1016/j.lithos.2013.08.015

Zhang, F.F., Wang, X.L., Sun, Z.M., Chen, X., Zhou, X.H., Yang, T., 2018. Geochemistry and zircon-apatite $\mathrm{U}-\mathrm{Pb}$ geochronology of mafic dykes in the Shuangxiwu area: constraints on the initiation of Neoproterozoic rifting in South China. Precambrian Research 309, 138151. doi:10.1016/j.precamres.2017.04.008

Zhang, Q., Zhai, M.G., 2012. What is the Archean TTG?. Acta Petrologica Sinica 28, 34463456.

Zhang, Y.Z., Wang, Y.J., 2016. Early Neoproterozoic ( 840 Ma) arc magmatism: geochronological and geochemical constraints on the meta-basites in the Central Jiangnan orogenic belt. Precambrian Research 275, 1-17. doi:10.1016/j.precamres.2015.11.006 
Zhao, G.C., Cawood, P.A., Wilde, S.A., Sun, M., 2002. Review of global 2.1-1.8 Ga collisional orogens and accreted cratons: a pre-Rodinia supercontinent?. Earth Science Reviews 59, 125-162. doi:10.1016/S0012-8252(02)00073-9

Zhao, G.C., Cawood, P.A., 2012. Precambrian geology of China. Precambrian Research 222, 13-54. doi:10.1016/j.precamres.2012.09.017

Zhao, J.H., Zhou, M.F., Zheng, J.P., 2013. Constraints from zircon U-Pb ages, O and Hf isotopic compositions on the origin of Neoproterozoic peraluminous granitoids from the Jiangnan Fold Belt, South China. Contributions to Mineralogy and Petrology 166, 1505-1519. doi:10.1007/s00410-013-0940-z

Zheng, J.P., Griffin, W.L., O’Reilly, S.Y., Zhang, M., Pearson, N., Pan, Y.M., 2006. Widespread Archean basement beneath the Yangtze craton. Geology 34, 417-420. doi:10.1130/G22282.1

Zhong, Y.F., Ma, C.Q., She, Z.B., Lin, G.C., Xu, H.J., Wang, R. J., Yang, K.G., Liu, Q., 2005. SHRIMP U-Pb zircon geochronology of the Jiuling granitic complex batholith in Jiangxi Province [in Chinese with English abstract]. Earth Science-Journal of China University of Geosciences 30, 685-591.

Zheng, Y.F., Zhang, S.B., Zhao, Z.F., Wu, Y.B., Li, X.H., Li, Z.X., Wu, F.Y., 2007. Contrasting zircon Hf and O isotopes in the two episodes of Neoproterozoic granitoids in South China: Implications for growth and reworking of continental crust. Lithos 96, 127-150. doi:10.1016/j.lithos.2006.10.003

Zheng, Y.F., Wu, R.X., Wu, Y.B., Zhang, S.B., Yuan, H.L., Wu, F.Y., 2008. Rift melting of juvenile arc-derived crust: geochemical evidence from Neoproterozoic volcanic and granitic 
rocks in the Jiangnan orogen, South China. Precambrian Research 163, 351-383. doi:10.1016/j.precamres.2008.01.004

Zhou C.M., 2016. Neoproterozoic lithostratigraphy and correlation across the Yangtze block, South china. Journal of Stratigraphy 40 (2), 120-135.

Zhou, J.C., Wang, X.L., Qiu, J.S., 2009. Geochronology of neoproterozoic mafic rocks and sandstones from northeastern guizhou, south china: coeval arc magmatism and sedimentation. Precambrian Research 170, 27-42. doi:10.1016/j.precamres.2008.11.002

Zhou, X.M., Zhou, H.B., Yang, J.D., Wang, Y.X., 1989. Sm-Nd isochron age of the ophiolite suite in Shexian county, Anhui province and its geological significance. Chinese Science Bulletin 35, 208-212.

\section{Figure captions}

Figure 1. Tectonic outline of China and geological sketch map of the Yangtze and Cathaysia blocks.

Figure 2. Geological sketch maps and cross-sections with sampling locations for (A) the Fanjingshan area, (B) the Sibao area and (C) the Madiyi area, and (D) simplified stratigraphic column of Neoproterozoic strata in the western Jiangnan Orogenic Belt.

Figure 3. Representative field photos and geologic sketch maps. (A) Unconformity between the Fanjingshan and the Xiajiang Groups in the Fanjingshan area; (A') Geologic sketch map of A with the unconformity contact relationship; (B) Conglomerate of the Xiajiang Group; (C) Unconformity between the Sibao and Danzhou Groups in the Sibao area; (C') Geologic sketch map of $\mathrm{C}$ with the unconformity contact relationship; (D, E) Conglomerate of the Danzhou Group; (F) Unconformity between the Lengjiaxi and Banxi Groups in the Madiyi area; (F') 
Geologic sketch map of $F$ with the unconformity contact relationship; $(G)$ Tight fold in the Lengjiaxi Group; (H) Conglomerate of the Banxi Group.

Figure 4. Representative photomicrographs of the samples. (A) Photomicrograph of Sample 1932 (matapsammite) in the Xiajiang Group collected from the Fanjingshan area; (B) Photomicrograph of Sample 1933 (sandy slate) in the Fanjingshan Group collected from the Fanjingshan area; (C) Photomicrograph of Sample 1714-1 (metapsammite) in the Danzhou Group collected from the Sibao area; (D) Photomicrograph of Sample 1714 (phyllite) in the Sibao Group collected from the Sibao area; (E) Photomicrograph of Sample 1399 (blastopsammite) in the Banxi Group collected from the Madiyi area; (F) Photomicrograph of Sample 1400 (sandy slate) in the Lengjiaxi Group collected from the Madiyi area. Qz: quartz; Chl: chlorite; Kfs: K-feldspar; Se: sericite; Ms: muscovite; Bt: biotite.

Figure 5. (A) Source rock discrimination diagrams for the samples on Hf versus La/Th (modified after Floyd and Leveridge, 1987) and (B) Plot of discriminant scores along Function I versus II for various samples (modified after Bhatia, 1983)

Figure 6. Distribution of (A) rare earth elements and (B) trace elements for the samples derived from the Jiangnan Orogen. The normalization values for (A) and (B) are taken from Sun and McDonough (1989) and McDonough and Sun (1995), respectively.

Figure 7. Representative cathodo-luminescence images of zircons of the samples from the Jiangnan Orogen, attached with analyzed locations and $\mathrm{U}-\mathrm{Pb}$ ages.

Figure 8. $\mathrm{U}-\mathrm{Pb}$ age concordia plots and histograms and relative probability plots for the zircon of six samples from the Jiangnan Orogen. 
Figure 9. Comparison of the $\mathrm{U}-\mathrm{Pb}$ age histograms and relative probability plots between the Sibao Group and its equivalents and Danzhou Group and its equivalents derived from the Jiangnan Orogen.

Figure 10. Comparison of the $\mathrm{U}-\mathrm{Pb}$ age histograms and relative probability plots derived from Neoproterozoic strata among the Yangtze Block, Jiangnan Orogen and Cathaysia Block.

Figure 11. Geodynamic evolutionary model for the Jiangnan region in the Early Neoproterozoic. (A) Subduction of the Paleo-South China Ocean and (B) Collision of the Yangtze and Cathaysia blocks.

\section{Table}

Table 1. Dating of the S-type granite plutons in the Jiangnan Orogenic Belt. 
Table 1

Dating of the S-type granite plutons in the Jiangnan Orogenic Belt

\begin{tabular}{|c|c|c|c|c|}
\hline Pluton & Area (province) & Age (Ma) & Method & Reference \\
\hline \multirow{2}{*}{ Miaohou } & \multirow{2}{*}{ Zhejiang } & & Zircon LA-ICPMS U- & \\
\hline & & $828 \pm 4$ & $\mathrm{~Pb}$ & Xia et al., 2015 \\
\hline \multirow{2}{*}{ Xiuning } & \multirow{2}{*}{ Anhui } & & Zircon LA-ICPMS U- & \\
\hline & & $825 \pm 7$ & $\mathrm{~Pb}$ & Wu et al., 2006 \\
\hline \multirow{2}{*}{ Dongma } & \multirow{2}{*}{ Guangxi } & & Zircon LA-ICPMS U- & \\
\hline & & $824 \pm 13$ & $\mathrm{~Pb}$ & Wang et al., 2006 \\
\hline \multirow{2}{*}{ Zhaigun } & \multirow{2}{*}{ Guangxi } & & Zircon LA-ICPMS U- & \\
\hline & & $836 \pm 3$ & $\mathrm{~Pb}$ & Wang et al., 2006 \\
\hline \multirow{2}{*}{ Fanjingshan } & \multirow{2}{*}{ Guizhou } & & Zircon LA-ICPMS U- & \\
\hline & & $838 \pm 2$ & $\mathrm{~Pb}$ & Wang et al., 2011 \\
\hline \multirow{2}{*}{ Nage } & \multirow{2}{*}{ Guizhou } & & Zircon LA-ICPMS U- & \\
\hline & & $852 \pm 5$ & $\mathrm{~Pb}$ & Wu et al., 2018 \\
\hline \multirow{3}{*}{ Bendong } & \multirow{3}{*}{ Guangxi } & $820 \pm 18$ & Zircon SHRIMP U-Pb & Zheng et al., 2007 \\
\hline & & & Zircon LA-ICPMS U- & \\
\hline & & $823 \pm 4$ & $\mathrm{~Pb}$ & Wang et al., 2006 \\
\hline \multirow{5}{*}{ Sanfang } & \multirow{5}{*}{ Guangxi-Guizhou } & & Zircon LA-ICPMS U- & \\
\hline & & $804 \pm 5$ & $\mathrm{~Pb}$ & Wang et al., 2006 \\
\hline & & $826 \pm 13$ & Zircon SHRIMP U-Pb & Zheng et al., 2007 \\
\hline & & & Zircon LA-ICPMS U- & \\
\hline & & $834 \pm 8$ & $\mathrm{~Pb}$ & Zhao et al., 2013 \\
\hline \multirow{6}{*}{ Jiulingshan } & \multirow{6}{*}{ Jiangxi } & & Zircon LA-ICPMS U- & \\
\hline & & $813 \pm 5$ & $\mathrm{~Pb}$ & Zhao et al., 2013 \\
\hline & & $819 \pm 9$ & Zircon SHRIMP U-Pb & Li et al. ,2003 \\
\hline & & $820 \pm 10$ & Zircon SHRIMP U-Pb & Zhong et al., 2005 \\
\hline & & $822+6$ & $\begin{array}{l}\mathrm{A}-\mathrm{ICPIMS} \text { - } \\
\mathrm{Pb}\end{array}$ & Zhao et al 2013 \\
\hline & & $828 \pm 8$ & Zircon SHRIMP U-Pb & Zhong et al., 2005 \\
\hline \multirow{8}{*}{ Yuanbaoshan } & \multirow{8}{*}{ Guangxi } & $823 \pm 5$ & $\begin{array}{c}\text { Zircon LA-ICPMS U- } \\
\mathrm{Pb}\end{array}$ & Yao et al., 2014a \\
\hline & & 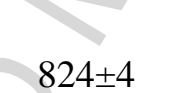 & $\begin{array}{c}\text { Zircon LA-ICPMS U- } \\
\text { Pb }\end{array}$ & Yao et al., 2014a \\
\hline & & & $\begin{array}{c}\text { Zircon LA-ICPMS U- } \\
\qquad \mathrm{Pb}\end{array}$ & Yao et al., 2014a \\
\hline & & $824 \pm 4$ & Zircon SHRIMP U-Pb & Zheng et al., 2007 \\
\hline & & & Zircon LA-ICPMS U- & \\
\hline & & $827 \pm 7$ & $\mathrm{~Pb}$ & Zhao et al., 2013 \\
\hline & & $831+5$ & $\begin{array}{l}\text { Zircon LA-ICPMS U- } \\
\qquad \mathrm{Pb}\end{array}$ & Yao et al., 2014a \\
\hline & & $833+6$ & $\begin{array}{c}\text { Zircon LA-ICPMS U- } \\
\mathrm{Ph}\end{array}$ & Yao et al., 2014a \\
\hline \multirow{13}{*}{ Xucun } & \multirow{13}{*}{ Anhui } & & Zircon LA-ICPMS U- & Wano et al $2012 \mathrm{~h}$ \\
\hline & & $804 \pm 7$ & $\mathrm{~Pb}$ & Wang et al. ,2012b \\
\hline & & $805 \pm 4$ & $\begin{array}{l}\text { Zircon LA-ICPMS U- } \\
\qquad \mathrm{Pb}\end{array}$ & Wang et al. ,2012b \\
\hline & & & Zircon LA-ICPMS U- & Thenget al 2008 \\
\hline & & $821 \pm 8$ & $\mathrm{~Pb}$ & Zneng et al., $200 \delta$ \\
\hline & & $823 \pm 8$ & Zircon SHRIMP U-Pb & Li et al., 2003 \\
\hline & & & Zircon LA-ICPMS U- & \\
\hline & & $823 \pm 7$ & $\mathrm{~Pb}$ & Wu et al., 2006 \\
\hline & & & Zircon LA-ICPMS U- & Zheng et al., 2008 \\
\hline & & $825 \pm 11$ & $\begin{array}{c}\text { Pb } \\
\text { Zircon LA-ICPMS U- }\end{array}$ & \\
\hline & & $827 \pm 7$ & $\begin{array}{c}\mathrm{Pb} \\
\mathrm{Pb}\end{array}$ & Wu et al., 2006 \\
\hline & & & Zircon LA-ICPMS U- & \\
\hline & & $852 \pm 6$ & $\mathrm{~Pb}$ & Xue et al., 2010 \\
\hline
\end{tabular}




\section{Research highlights}

$>$ The subduction of the Paleo-South China Ocean started at ca. $1000 \mathrm{Ma}$ and ended at ca. $865 \mathrm{Ma}$.

- The Jiangnan Orogenic Belt was built up due to the assembly of the Yangtze and Cathaysia blocks between ca. 865 and $820 \mathrm{Ma}$.

$>$ The deposition of the Sibao Group lasted from ca. $1000 \mathrm{Ma}$ to $820 \mathrm{Ma}$. 


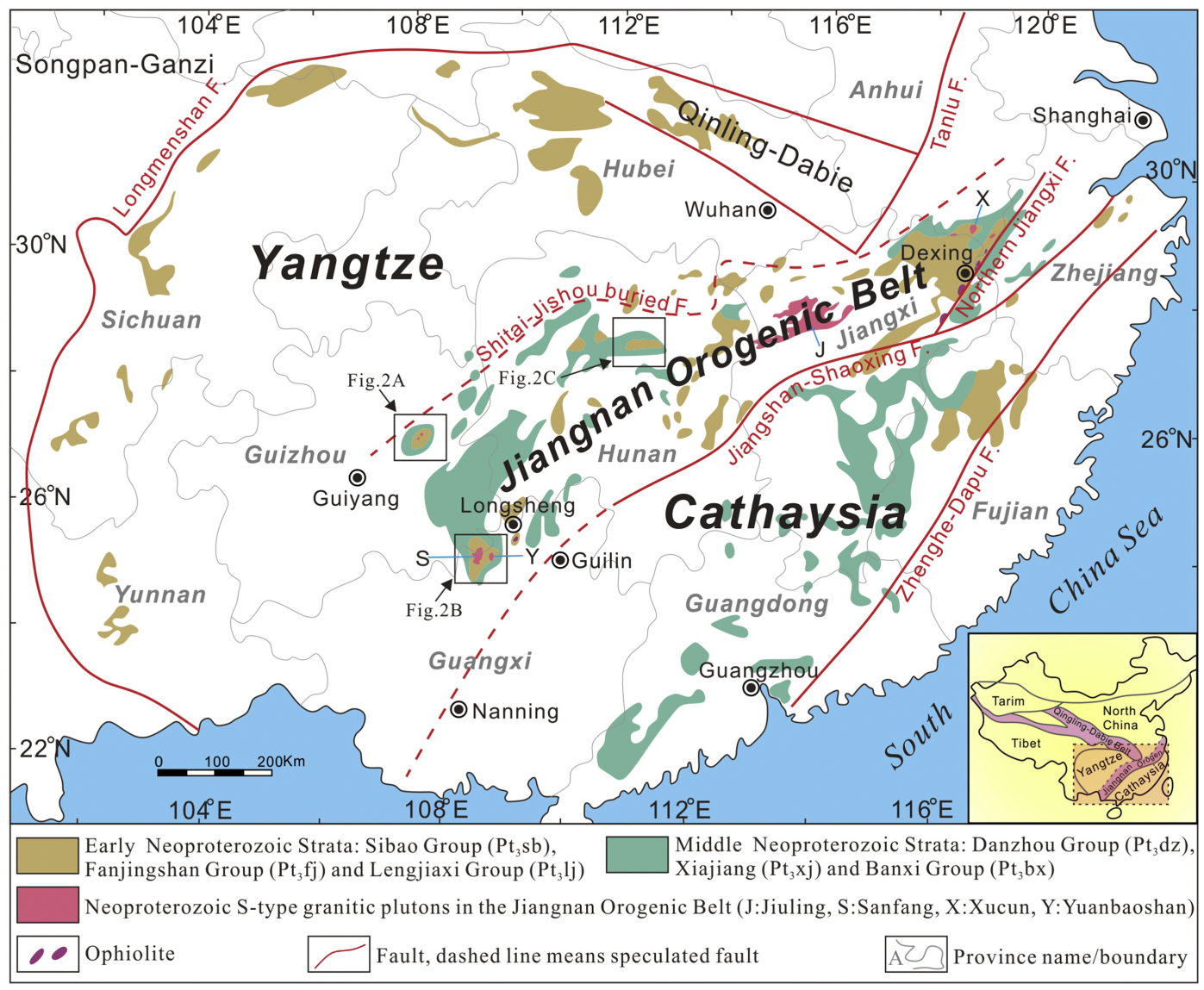

Figure 1 

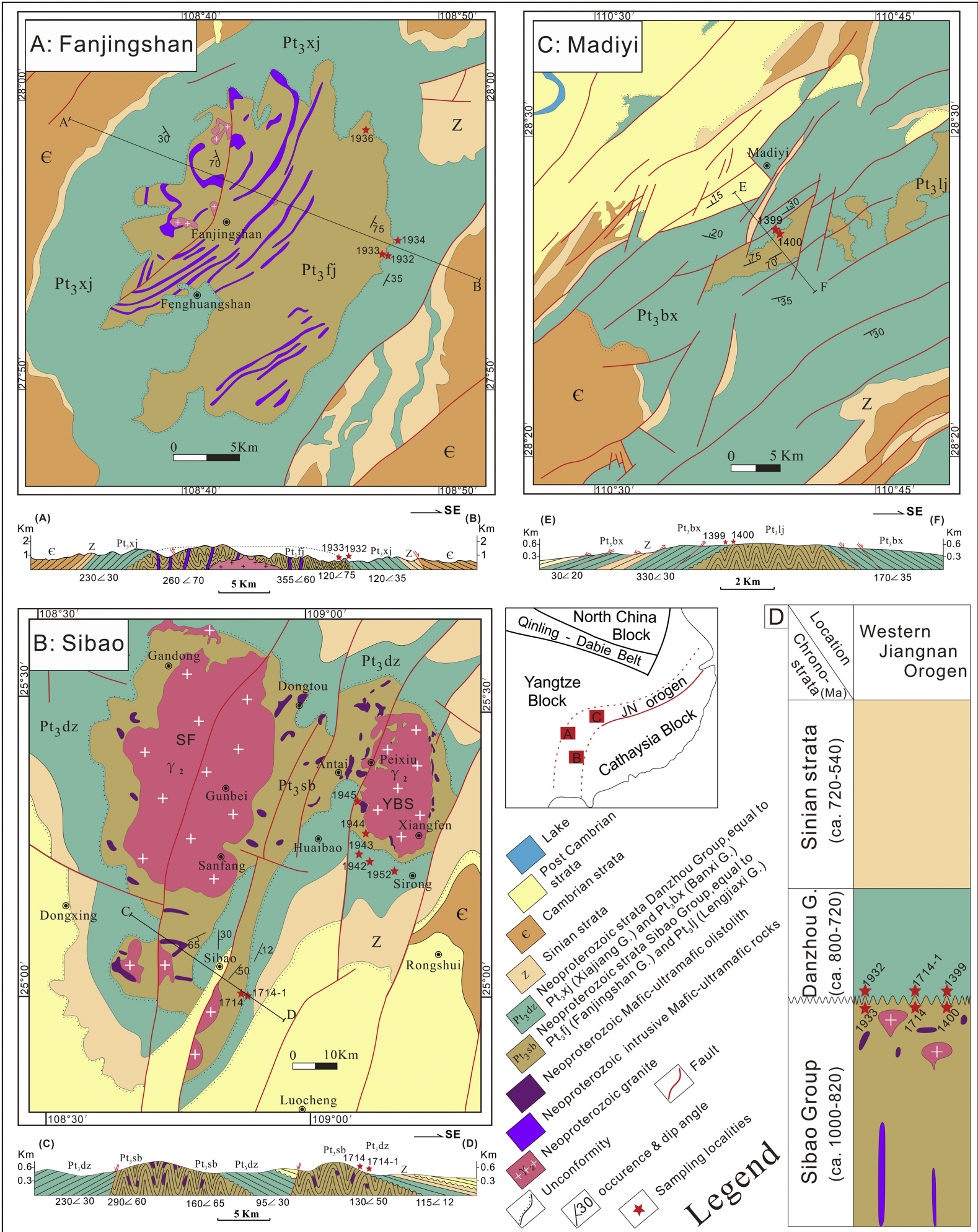


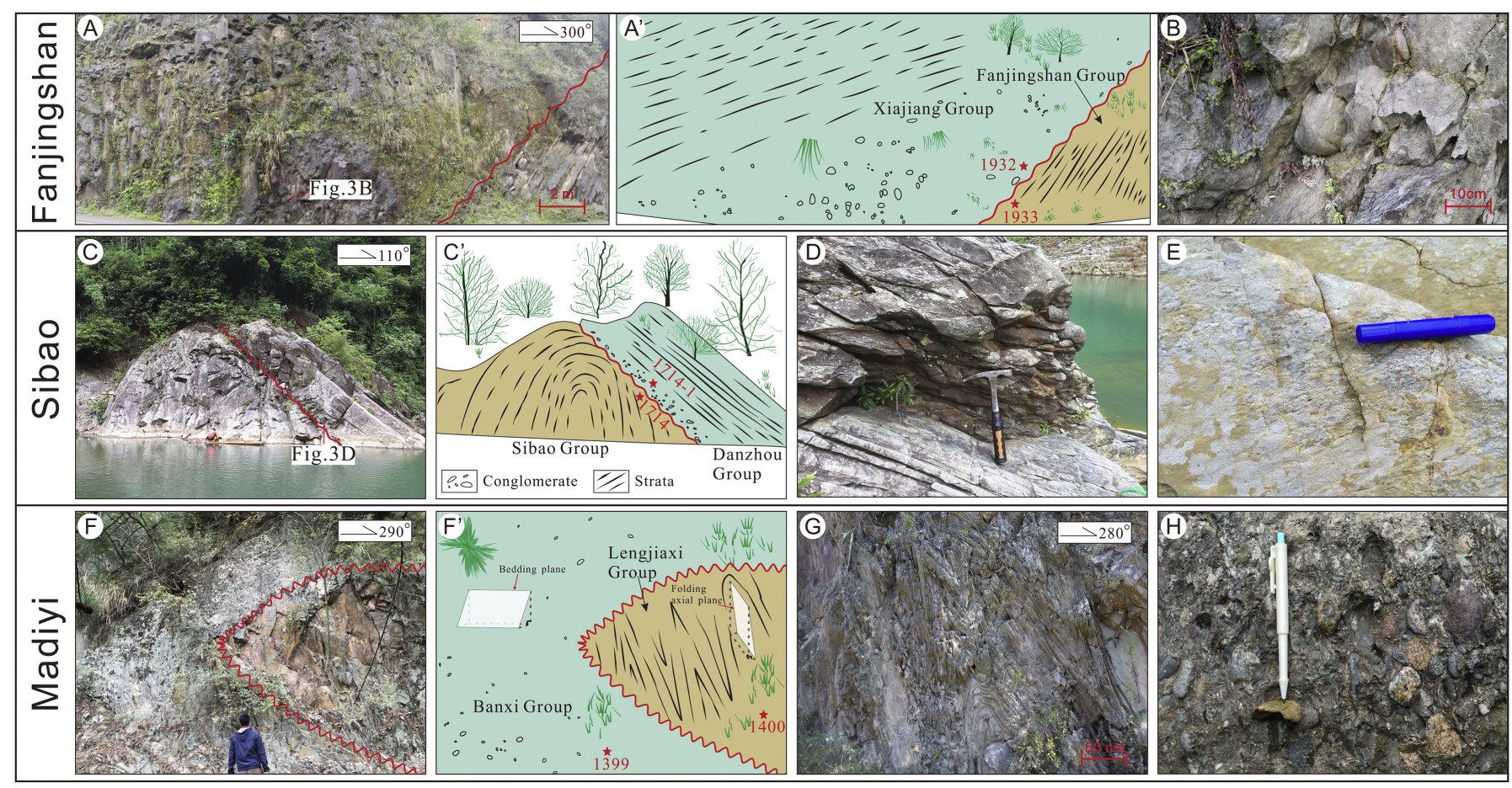

Figure 3 


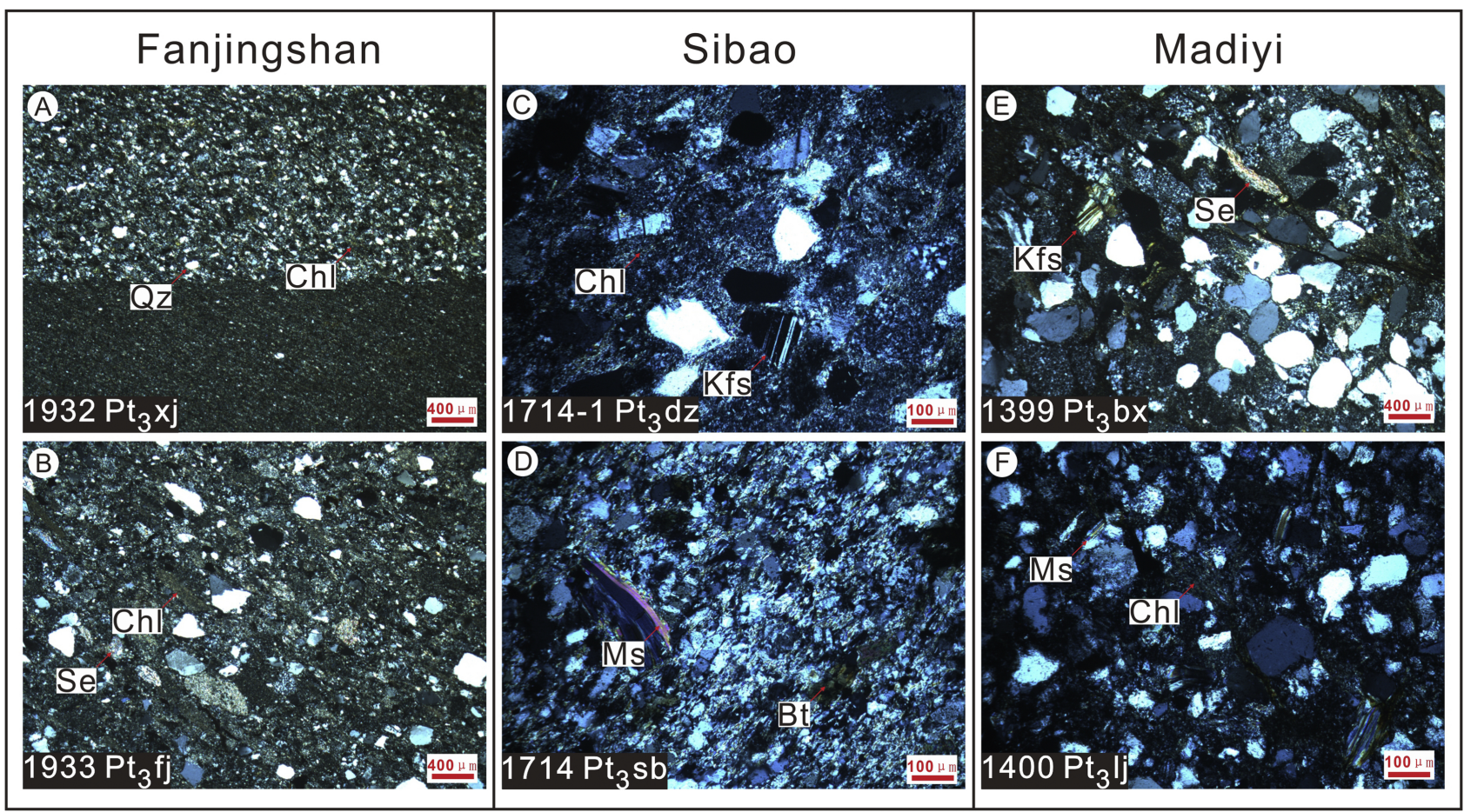

Figure 4 

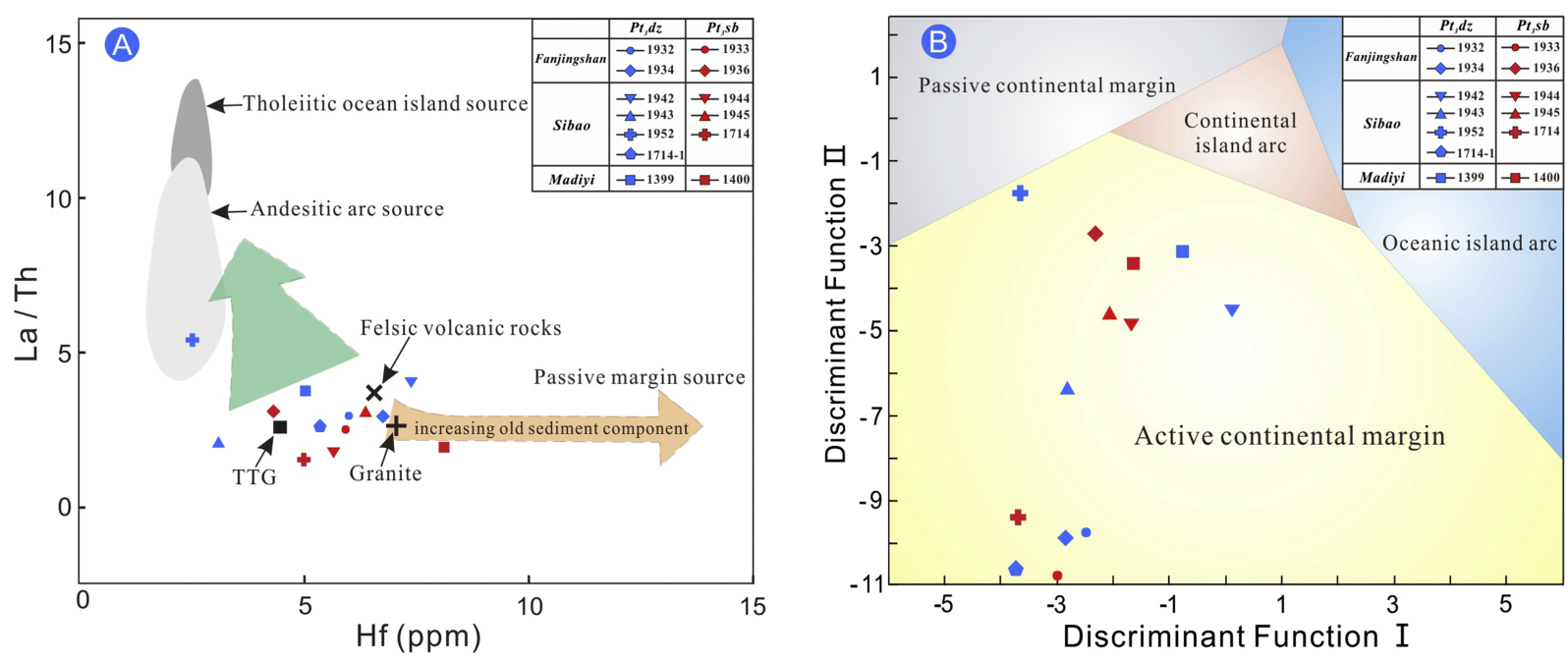

Figure 5 

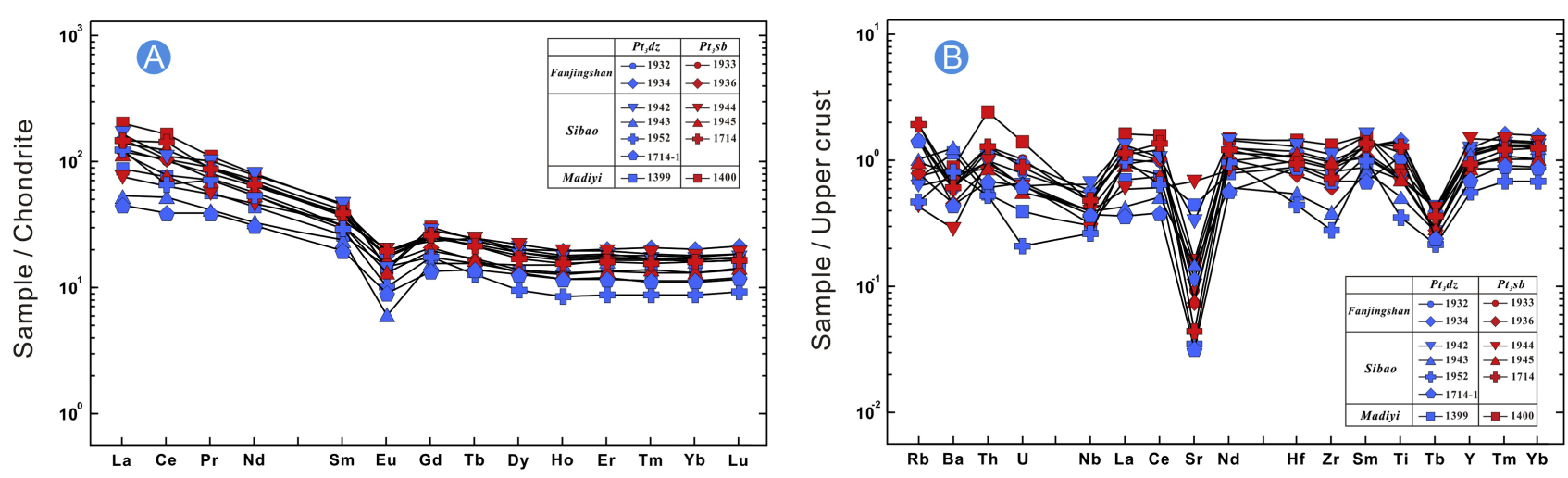

Figure 6 


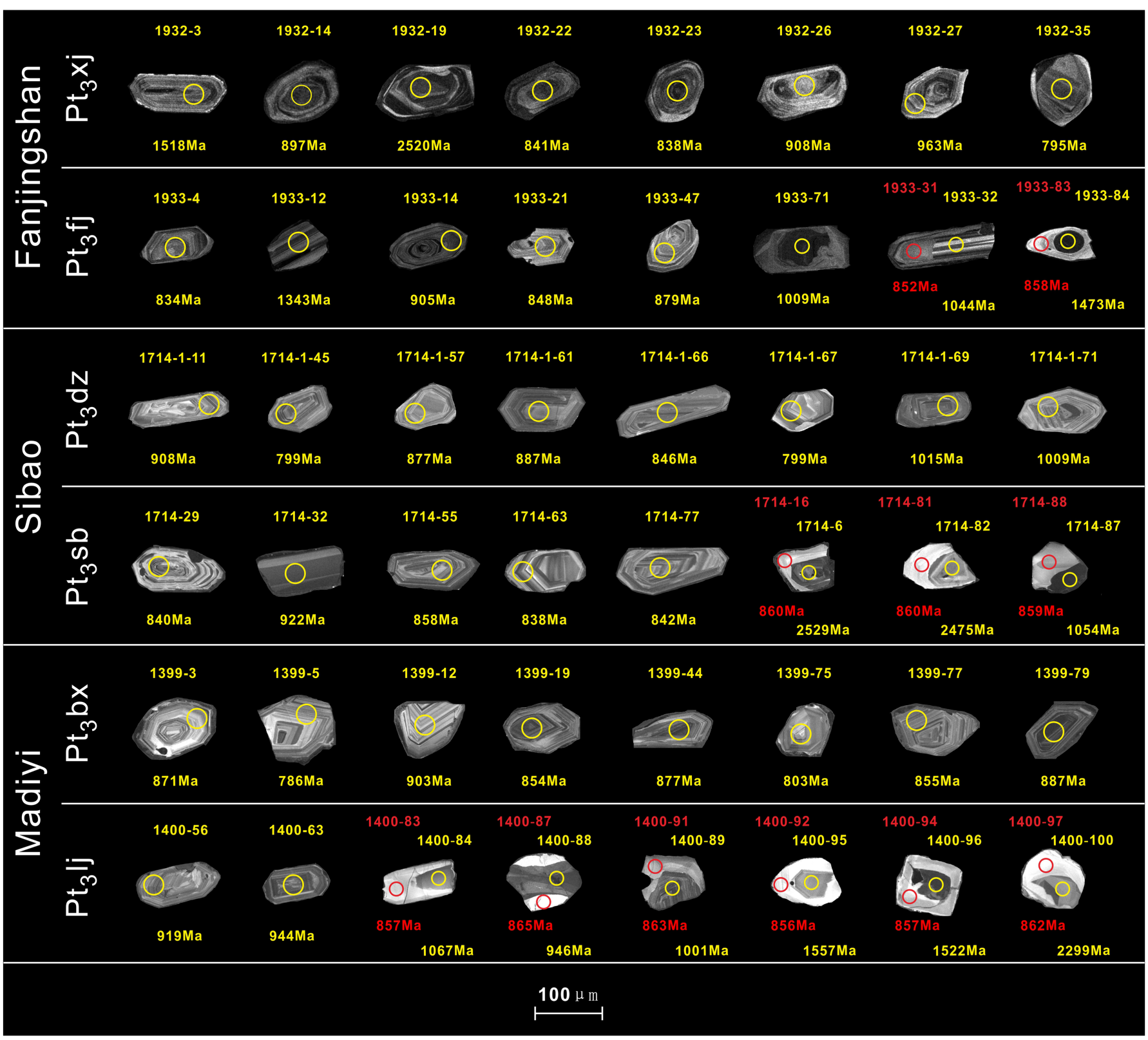

Figure 7 


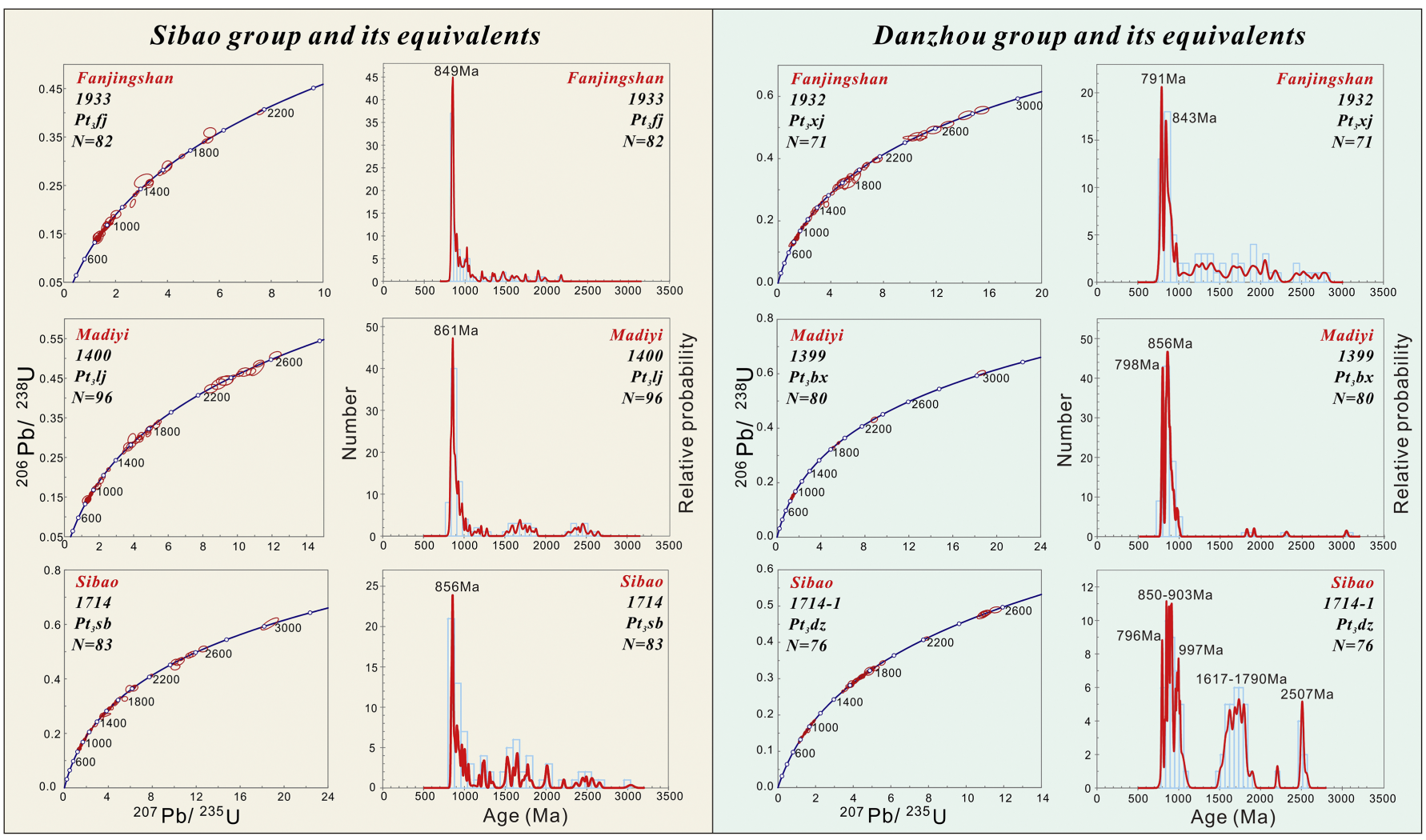

Figure 8 


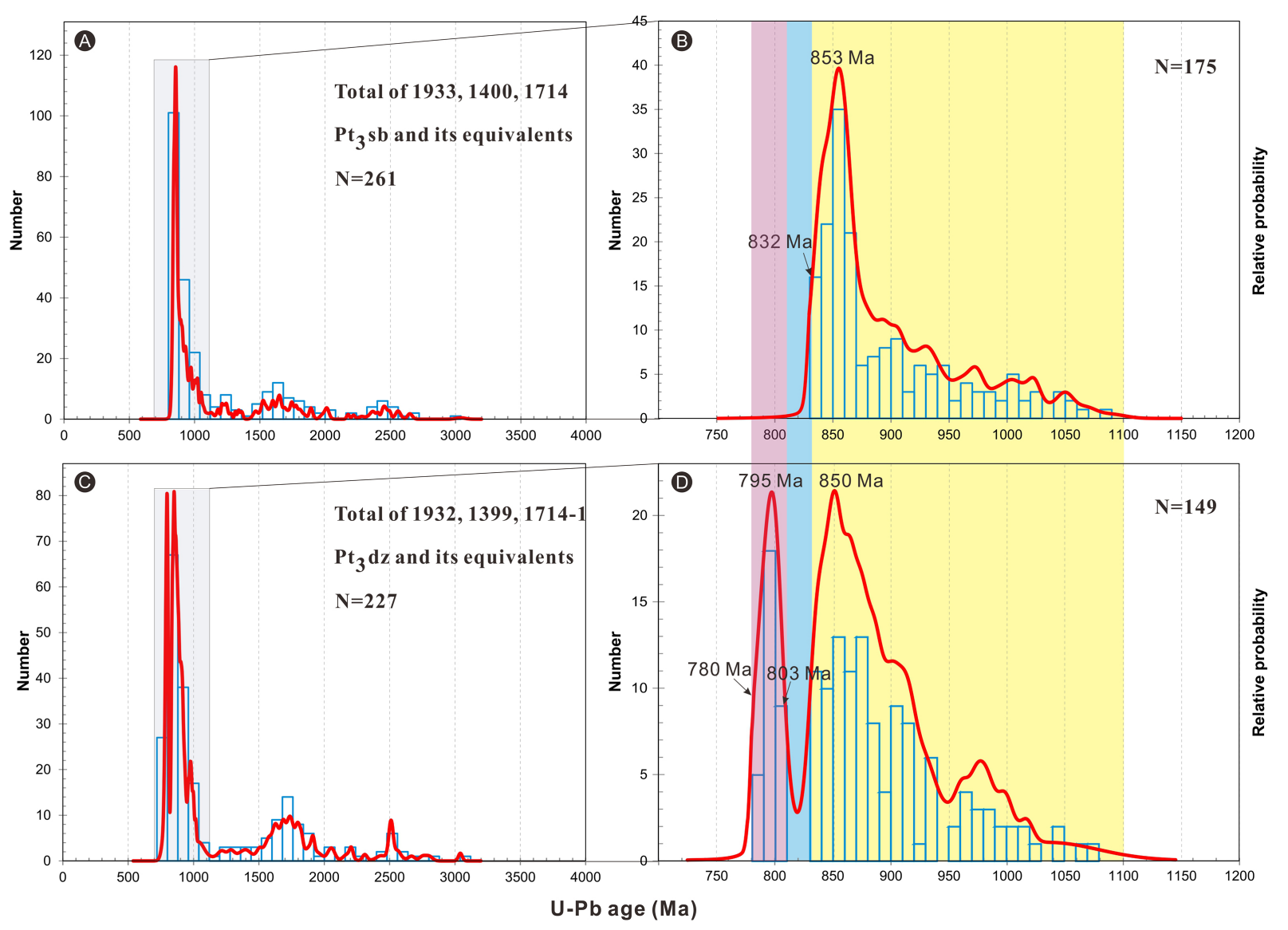

Figure 9 

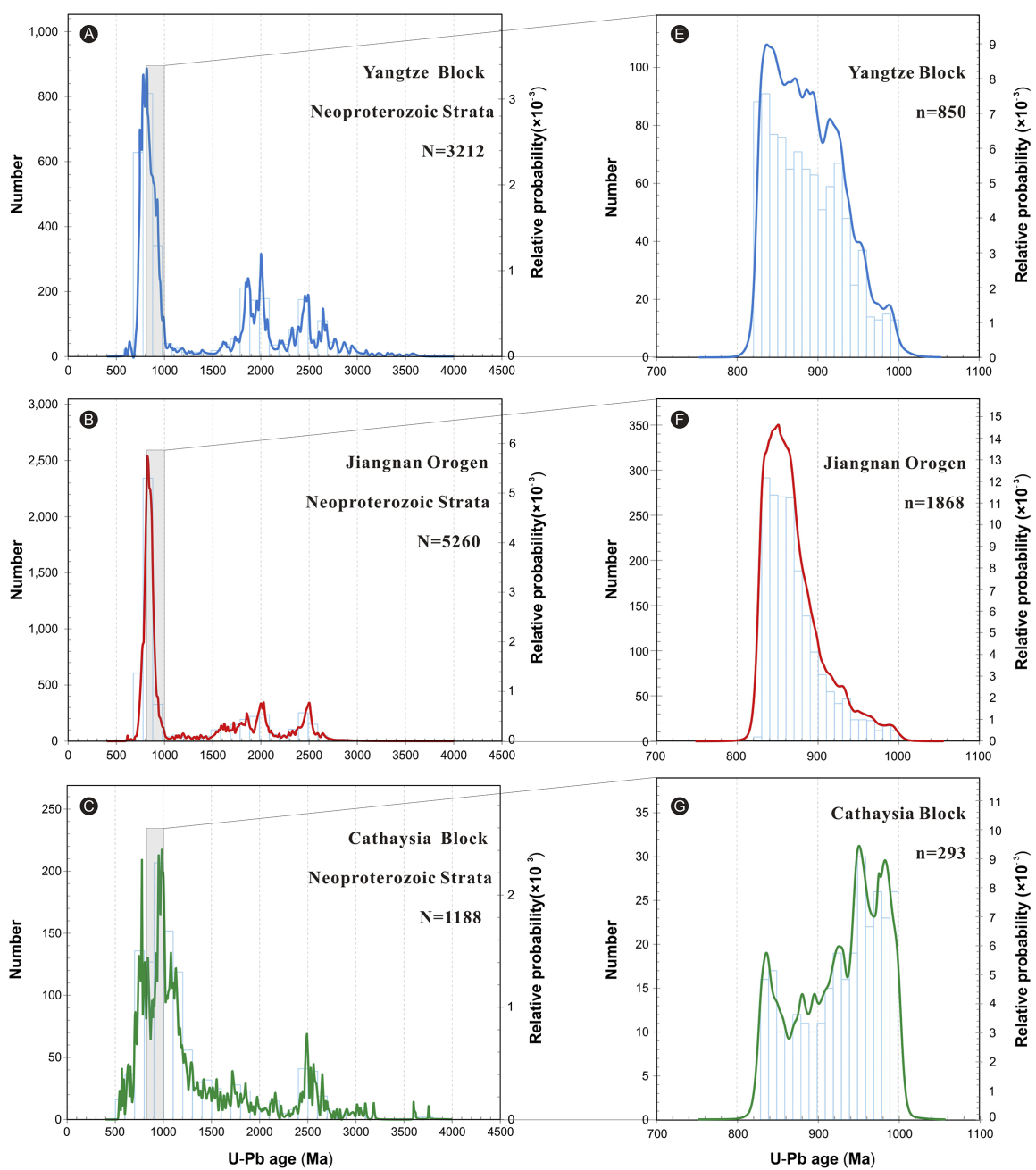
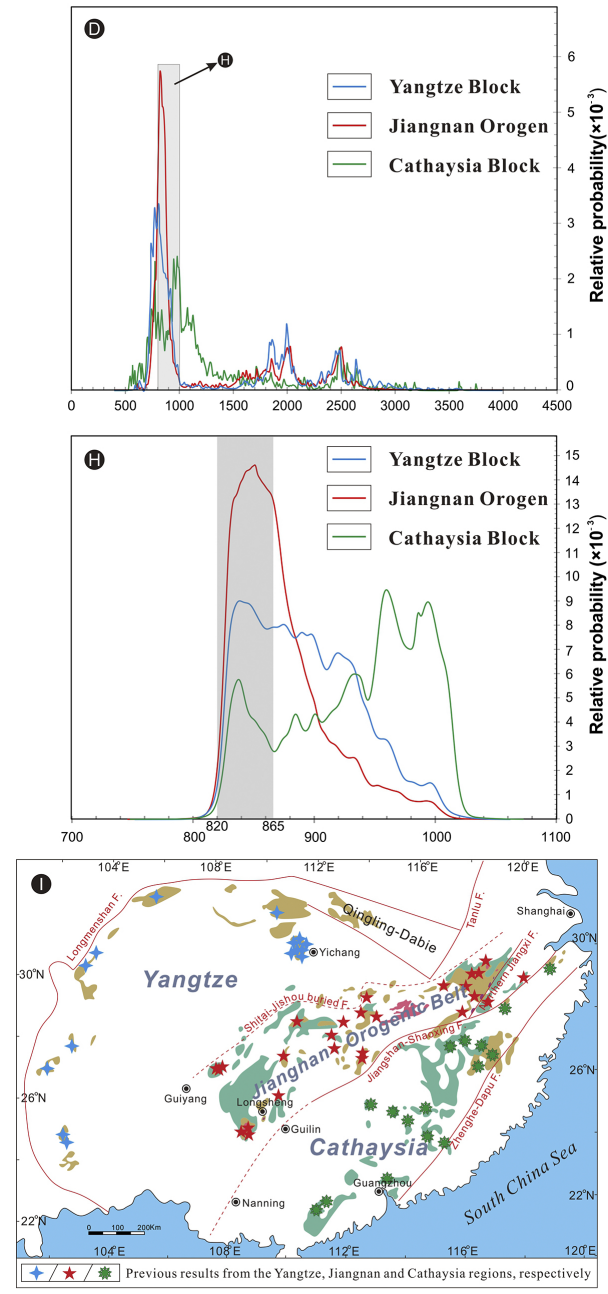

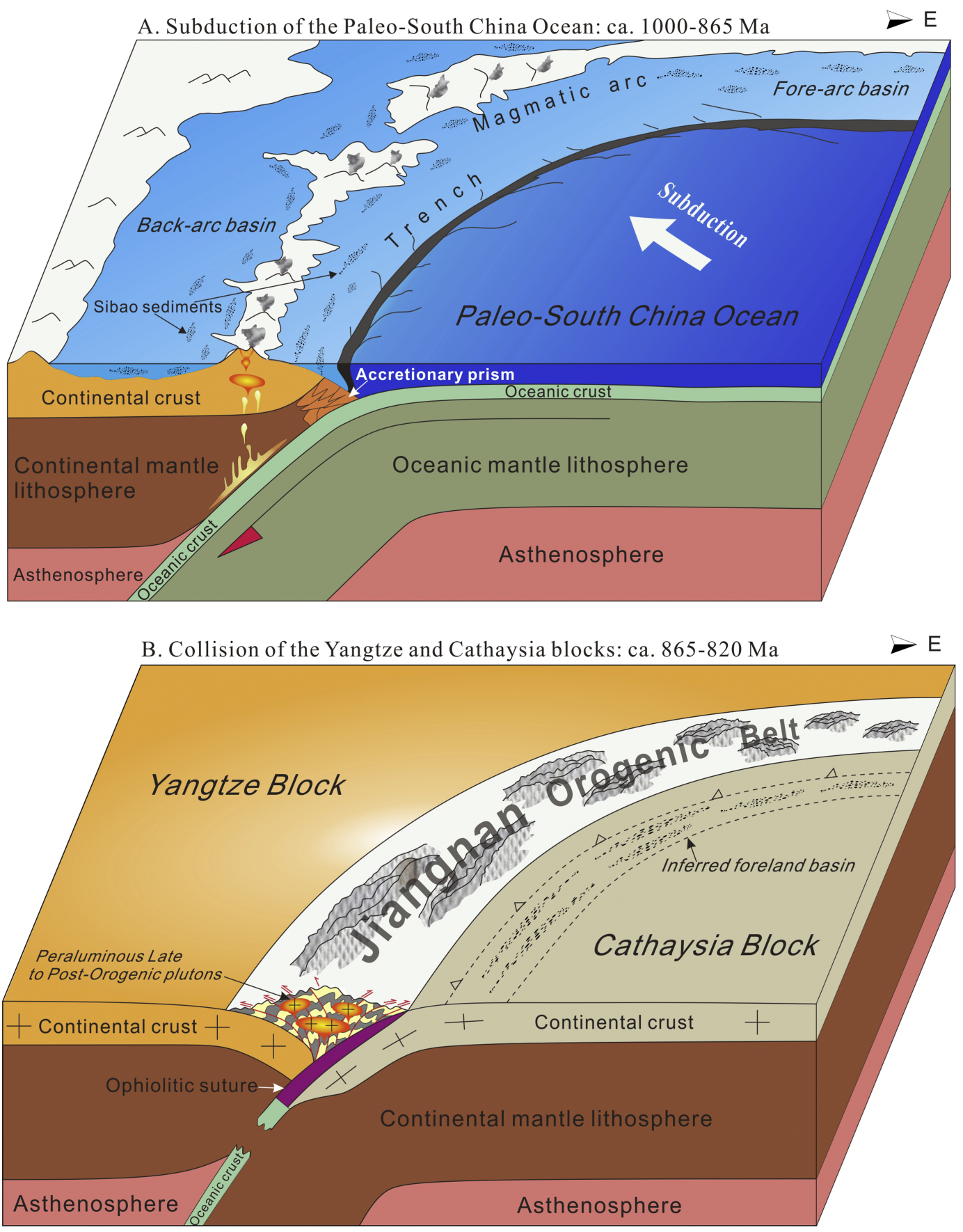